\title{
Beschikbaarheid van vis voor visdieven rond Marker Wadden in juli 2020
}

Author(s): Joep J. de Leeuw, Olvin van Keeken, Cees Meeldijk, Martin Poot

Wageningen Marine Research

E

Martin Poot Ecology

WAGENINGEN

UNIVERSITY \& RESEAREH
Wageningen University \&

Research report C099/20 


\section{Beschikbaarheid van vis voor visdieven rond Marker Wadden in juli 2020}

Auteur(s): Joep J. de Leeuw, Olvin van Keeken, Cees Meeldijk, Martin Poot

Wageningen Marine Research

Martin Poot Ecology

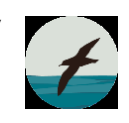


Keywords: voedselbeschikbaarheid, helderheid, prooivis, visdief, Markermeer, IJsselmeer

Opdrachtgever: Deltares

T.a.v.: Sacha de Rijk

Boussinesqweg 1

2629 HV Delft

Dit rapport is gratis te downloaden van https://doi.org/10.18174/535076

Wageningen Marine Research verstrekt geen gedrukte exemplaren van rapporten.

Wageningen Marine Research is ISO 9001:2015 gecertificeerd.

Foto omslag: Joep de Leeuw

\section{(C) Wageningen Marine Research}

Wageningen Marine Research, instituut binnen de rechtspersoon Stichting

Wageningen Research, hierbij

vertegenwoordigd door

Dr. ir. J.T. Dijkman, Managing director

KvK nr. 09098104,

WMR BTW nr. NL 8113.83.696.B16.

Code BIC/SWIFT address: RABONL2U

IBAN code: NL 73 RABO 0373599285
Wageningen Marine Research aanvaardt geen aansprakelijkheid voor gevolgschade, noch voor schade welke voortvloeit uit toepassingen van de resultaten van werkzaamheden of andere gegevens verkregen van Wageningen Marine Research. Opdrachtgever vrijwaart Wageningen Marine Research van aanspraken van derden in verband met deze toepassing.

Alle rechten voorbehouden. Niets uit deze uitgave mag weergegeven en/of gepubliceerd worden, gefotokopieerd of op enige andere manier gebruikt worden zonder schriftelijke toestemming van de uitgever of auteur. 


\section{Inhoud}

$\begin{array}{lr}\text { Samenvatting } & 4\end{array}$

$1 \quad$ Inleiding $\quad 5$

2 Kennisvraag $\quad 7$

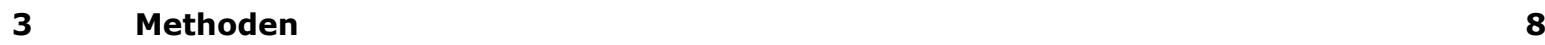

3.1 Vogeltellingen $\quad 8$

3.2 Visbemonsteringen en vogeltellingen vanaf het water 9

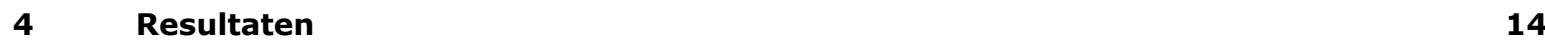

4.1 Helder/troebel water $\quad 14$

4.2 Verspreiding van foeragerende visdieven op basis van tellingen vanuit vliegtuig 16

$\begin{array}{lll}4.3 & \text { Verticale verspreiding prooivis } & 22\end{array}$

4.4 Aantallen en gedrag van visdieven bij visbemonsteringslocaties 24

$\begin{array}{ll}4.5 & \text { Waargenomen prooikeuze } \\ \end{array}$

$5 \quad$ Conclusies en aanbevelingen $\quad 29$

5.1 Ruimtelijke verspreiding foerageergebieden en prooikeuze 29

$\begin{array}{ll}5.2 & \text { Aanbevelingen } \\ \end{array}$

$\begin{array}{llr}6 & \text { Kwaliteitsborging } & 34\end{array}$

$\begin{array}{ll}\text { Literatuur } & 35\end{array}$

$\begin{array}{lr}\text { Verantwoording } & 36\end{array}$ 


\section{Samenvatting}

In het kader van het Kennis- en Innovatieprogramma Marker Wadden (KIMA) is in juli 2020 onderzoek gedaan naar de foerageergebieden en prooikeuze van visdieven die broeden op Marker Wadden. In aanvulling op lopend onderzoek naar de voedselkeuze van visdieven in relatie tot het broedsucces was de belangrijkste onderzoeksvraag in dit project waar de belangrijkste foerageergebieden liggen en welke omstandigheden bepalen wanneer vis die geschikt is als prooi voor visdieven bereikbaar is voor visdieven. Hiertoe zijn drie tellingen vanuit een vliegtuig uitgevoerd waarbij de aantallen foeragerende visdieven werden genoteerd en waar mogelijk omstandigheden die van invloed zijn bij de keuze van de foerageergebieden, bijvoorbeeld de aanwezigheid van foeragerende aalscholvers en activiteiten van (vissers)schepen. Daarnaast zijn er in 3 perioden van 2-3 dagen vanaf een visserschip bemonsteringen uitgevoerd van potentiele prooivis voor visdieven. Hierbij werden met een fijnmazige broedkor bemonsteringen aan het wateroppervlak, halverwege de waterkolom en bij de bodem uitgevoerd in het zuidwestelijk IJsselmeer en oostelijk Markermeer. Ook werden aantallen foeragerende sterns geteld en waar mogelijk de prooikeuze vastgesteld aan de hand van foto's die op locatie werden gemaakt. Visdieven bleken verspreid over het relatief troebele Markermeer (Secchi 0.3$1.0 \mathrm{~m}$ ) te foerageren en volgden soms vrachtschepen. In het aanzienlijk helderder zuidwestelijke deel van het IJsselmeer (Secchi 1.0-3.0 m) bleken visdieven geconcentreerd in vaak grotere groepen tot maximaal 150 individuen te foerageren, niet zelden samen met foeragerende aalscholvers en futen. Ook werden foeragerende visdieven (ca 25\% tijdens de tellingen) aangetroffen bij vissersschepen die aalfuiken leegden langs de Houtribdijk. In het open water van IJsselmeer en Markermeer werd hoofdzakelijk spiering aangetroffen als geschikte prooi en werden, met name op het IJsselmeer, veel visdieven met spiering waargenomen die richting de broedkolonies vlogen op Marker Wadden en Trintelzand. Daarnaast bleek driedoornige stekelbaars veelvuldig voor te komen in de bovenste waterlagen in het IJsselmeer en werd waargenomen dat visdieven die ook aten maar niet naar de broedkolonies brachten. Nabij vissersschepen en aalfuiken langs de dijk werd een aanzienlijk gevarieerder dieet waargenomen waaronder ook bodemsoorten als pos en zwartbekgrondel die naar alle waarschijnlijkheid afkomstig was uit bijvangst van aalfuiken. Waarnemingen in de foerageergebieden blijken daarmee belangrijke aanvullingen te leveren op waarnemingen aan het dieet in de broedkolonies en inzicht in de (grote) betekenis van interacties tussen visdieven, andere visetende watervogels als aalscholvers en futen, en menselijke activiteiten als scheepvaart en visserij. 


\section{Inleiding}

Marker Wadden is een nieuw aangelegd natuurgebied in het Markermeer en bestaat uit een vijftal eilanden die zijn aangelegd ter versterking van het ecosysteem van het Markermeer. Binnen het Kennis- en Innovatieprogramma Marker Wadden (KIMA) wordt intensief onderzoek verricht naar de productiviteit van Marker Wadden en omringende wateren voor onder meer vis en vogels. De inspanningen tot dusver zijn geconcentreerd op informatie die direct in relatie staat tot de leefomgeving van Marker Wadden. Marker Wadden is ook onderdeel van het grotere Markermeer systeem en dus afhankelijk van het ecologisch functioneren van het IJsselmeergebied. Een van de karakteristieke elementen van de vogelfauna van Marker Wadden zijn de broedkolonies visdieven op de verschillende eilanden. Visdieven leven van kleine vis en hun broedsucces is afhankelijk van de kwaliteit van visproductie in het IJsselmeergebied (van der Winden et al. 2019a).

Op Marker Wadden broeden sinds de aanleg in 2016/2017 vele honderden visdieven en deze brengen veel kuikens groot. De belangrijkste prooitypen voor de visdieven in het IJsselmeergebied bestaan uit kleine vissen: spiering, pos en jonge baars en snoekbaars. Tussen en binnen seizoenen verschilt het aandeel van deze prooisoorten echter sterk (Van der Winden et al. 2019, Van der Winden \& Dreef 2020). Visdieven foerageren niet of nauwelijks in de directe omgeving van Marker Wadden en daarom rijst de vraag waar ze hun voedsel vandaan halen en welke factoren de voedselbeschikbaarheid bepalen.

Naast de verspreiding van vissen is de vangbaarheid ook relevant. Visdieven kunnen immers alleen vissen vangen die dicht aan het oppervlak zitten, terwijl de meeste vissen zich dieper in de waterkolom ophouden. Echter, afhankelijk van windrichting, troebelheid, voedselbeschikbaarheid, daglicht, aanwezigheid van roofvis of andere visetende watervogels, kan potentiële prooivis zich tijdelijk in de bovenste waterlagen bevinden en vangbaar ('beschikbaar') zijn voor visdieven. Door de dynamische aard van de ruimtelijke verdeling van jonge vis (zowel waar vissen in hogere concentraties voorkomen, als welk deel zich aan het oppervlak bevindt, variërend met de omstandigheden) is het niet eenvoudig om bruikbare informatie over de link tussen beschikbaarheid van prooivis en de benutting door visdieven te verkrijgen. Daarvoor zijn gerichte onderzoeksinspanningen noodzakelijk. Alleen door gericht onderzoek kan bekeken worden hoe effecten van aanleg, baggerwerkzaamheden, het ontstaan van luwtes (afhankelijk van windrichting), en de interacties met andere vogels, vissen en menselijke activiteiten bepalen hoe de actuele voedselbeschikbaarheid van visdieven eruit ziet en hoe die zich in de toekomst kan ontwikkelen.

In juli 2020 is in het kader van Ecoshape/KIMA een eerste aanzet gedaan om de complexe relaties tussen de abiotische en biotische omstandigheden in kaart te brengen die bepalen waar visdieven foerageren en welke vis gevangen wordt en aan de jongen in de kolonies van Marker Wadden worden gevoerd. De belangrijke vraag die we hiermee proberen op te lossen is welke omstandigheden bepalen wanneer vis die geschikt is als prooi voor visdieven bereikbaar is voor visdieven. Daarbij proberen we antwoorden te vinden op de onderzoeksvragen:

- Hoe is de ruimtelijke verspreiding van (foeragerende) visdieven en waar bevinden zich de belangrijkste foerageergebieden rond Marker Wadden binnen een gebied dat zich uitstrekt van het noordelijk en oostelijk deel van het Markermeer tot het zuidwestelijk deel van het IJsselmeer?

- Hoe hangen de belangrijkste foerageerlocaties samen met windcondities en de helderheid van het water?

- Hoe is de verticale verdeling van potentiele prooivis voor visdieven over de waterkolom en in het bijzonder de relatieve hoeveelheid vis dicht aan het oppervlak binnen bereik van visdieven?

- Hoe hangt de ruimtelijk verspreiding van prooivis af van windcondities en helderheid van het water? 
- Hoe hangt de verspreiding van vis (in ruimte en voorkomen aan oppervlak) af van eventueel andere oorzaken zoals de aanwezigheid van duikende visetende watervogels (aalscholvers en futen) en visserijactiviteiten (legen van aalfuiken)?

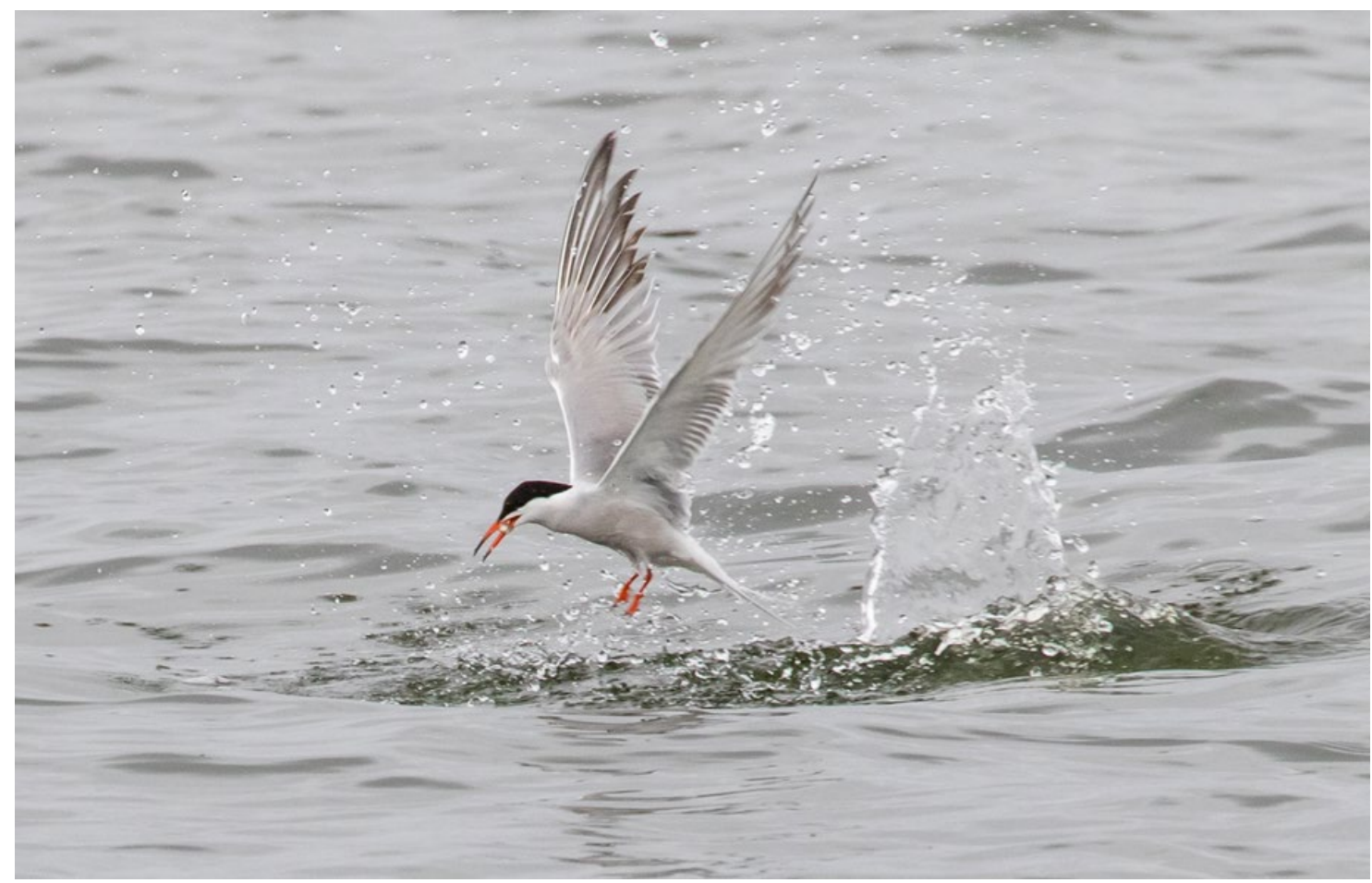

Afbeelding 1 Visdief met net gevangen jonge spiering in het IJsselmeer (foto: Joep de Leeuw). 


\section{Kennisvraag}

Om inzicht te krijgen in hoe de voedselomstandigheden de prooikeuze en het broedsucces bepalen van visdieven op Marker Wadden, is kennis van de beschikbaarheid van prooivis in de omgeving van Marker Wadden van belang. Het gaat daarbij vooral om omstandigheden van troebel-/helderheid van het water en interacties met andere visetende soorten vogels en vissen die de verspreiding, zowel in de ruimte als over de waterkolom, bepalen van soorten en lengtegroepen prooivis. De belangrijkste kennisvraag is om factoren te identificeren die de beschikbaarheid van prooivis (aan het wateroppervlak) bepalen en daarmee de foerageerlocaties en voedselkeuze van visdieven die broeden op Marker Wadden.

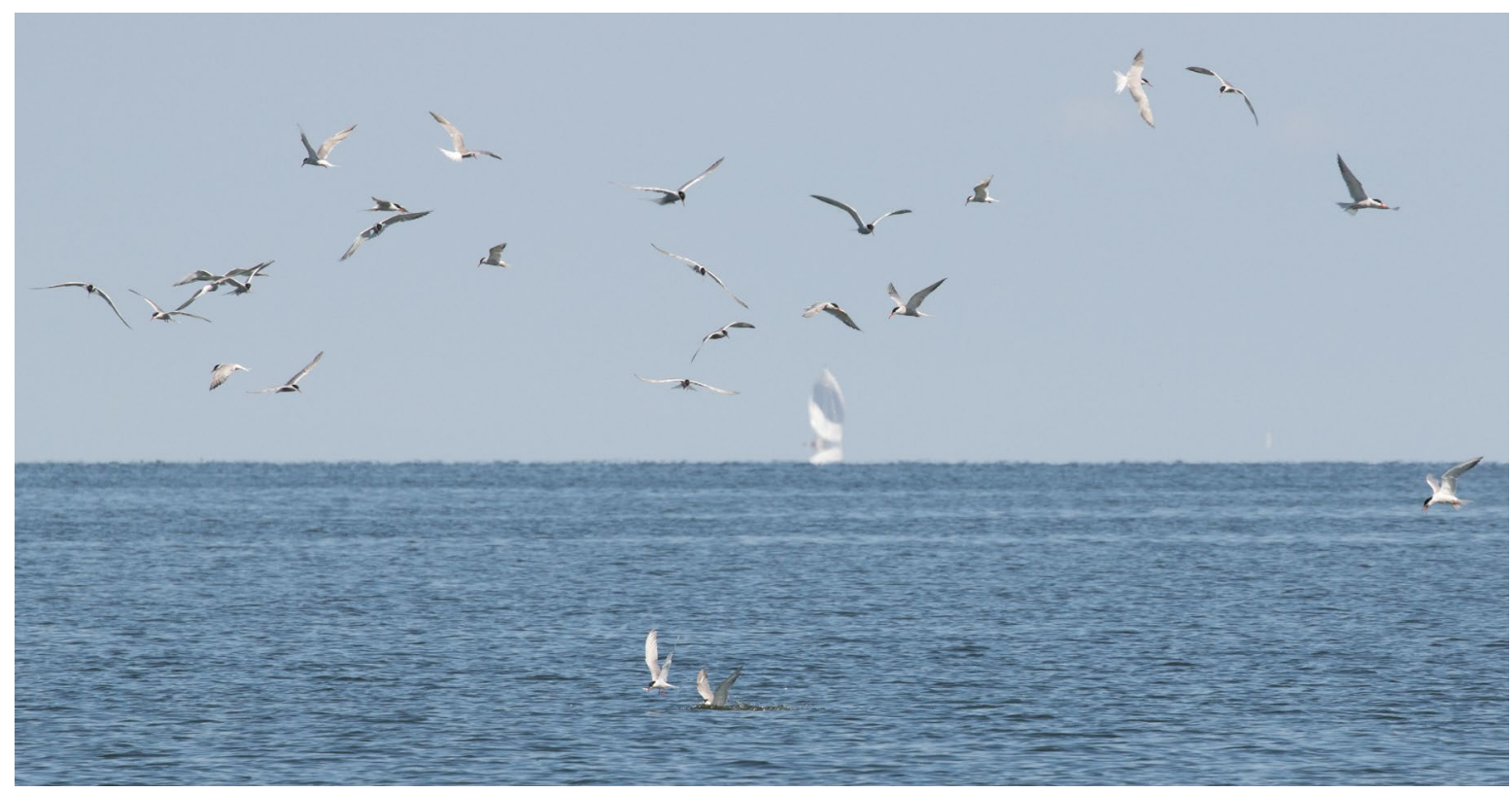

Afbeelding 2 Visdieven foeragerend op een school driedoornige stekelbaars en spiering in het IJsselmeer (foto: Joep de Leeuw). 


\section{Methoden}

Om grip te krijgen op de link tussen de dynamische en tijdelijke beschikbaarheid van prooivis en de benutting van die dynamische beschikbaarheid door visdieven zijn een aantal acties parallel uitgevoerd. Deze acties zijn:

- Visdieftellingen vanuit een vliegtuig om verspreiding van foeragerende visdieven in kaart te brengen.

- Visstandbemonsteringen met een broedkor.

- Visdieftellingen vanaf een schip (tegelijk met visstandbemonsteringen)

\subsection{Vogeltellingen}

Aantallen en verspreiding op het open water van visdief zijn vanuit een vliegtuig (Cessna) in kaart gebracht op basis van systematisch vastgestelde transecten die een groot deel van het potentiele foerageergebied van visdieven die broeden op Marker Wadden bestrijken (oostelijk Markermeer en zuidwestelijk IJsselmeer).

Er zijn drie tellingen van visdieven op het open water uitgevoerd op respectievelijk 2, 8 en 22 juli door middel van parallelle transecten over het studiegebied. In deze periode waren in de kolonies jonge visdieven van variërende leeftijd aanwezig, dat wil zeggen dat visdieven intensief foerageerden en vis naar de kolonie transporteerden. Voor nadere details over de methodiek en resultaten zie Poot et al. 2020.

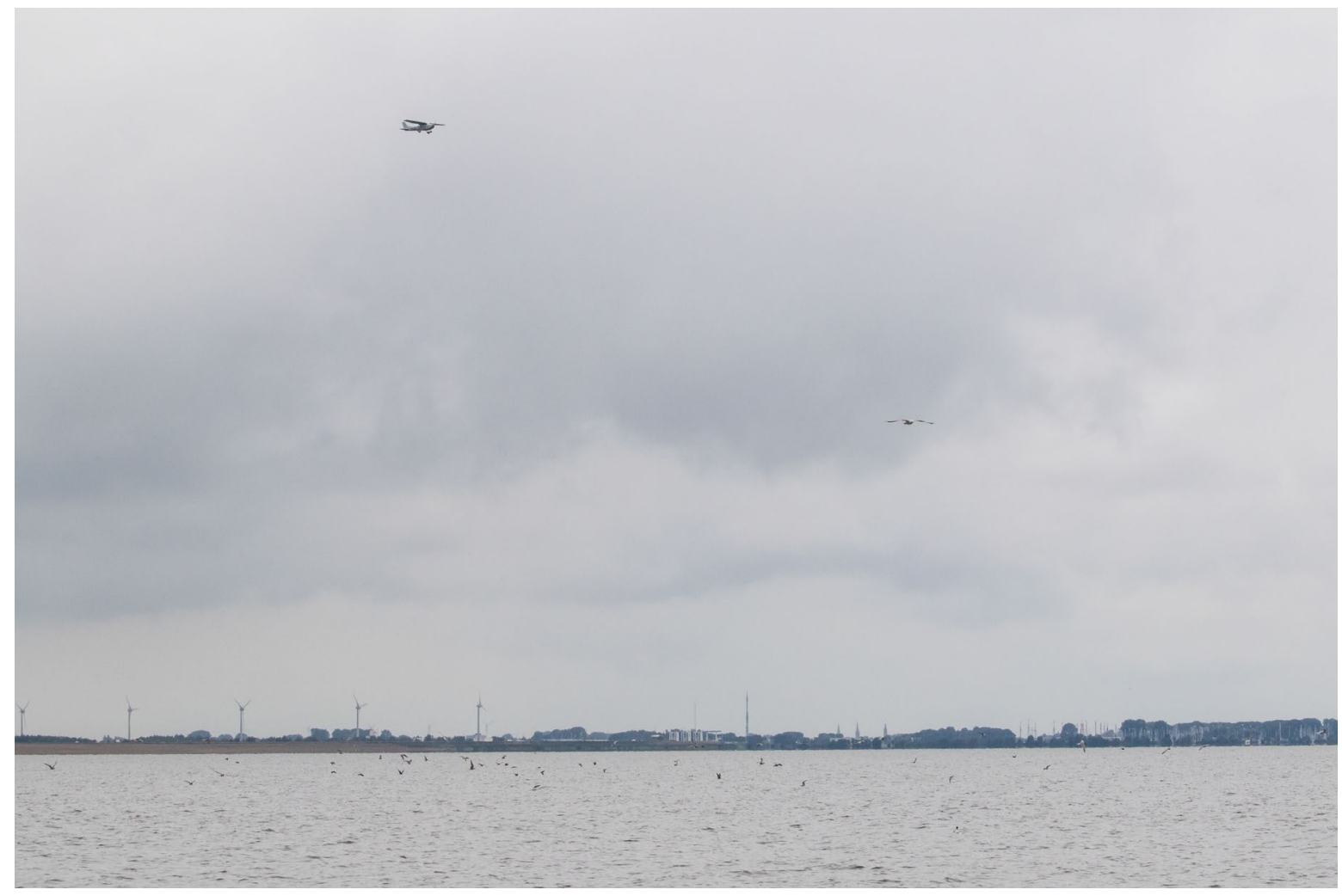

Afbeelding 3 Visdieftelling vanuit een Cessna (foto: Joep de Leeuw).

Van alle vliegende en foeragerende visdieven werd het gedrag (foerageren, al dan niet vis in de snavel) en de vliegrichting genoteerd. Ook werd genoteerd of visdieven foerageerden in associatie met andere foeragerende vogels (aalscholvers), activiteiten van vissersschepen of dat schepen werden gevolgd. 
$\mathrm{Bij}$ de visdievenkolonie op Marker Wadden zelf is onderzocht welke prooisoorten aangevoerd werden, hoe de kuikens groeiden, wat het broedsucces was en gegevens over aanvoerfrequentie werden met camera's verzameld. Dat was geen onderdeel van dit onderzoek, maar enkele resultaten zoals gepubliceerd in Van der Winden \& Dreef (2020) zijn wel benut voor de integratie van de gegevens.

\subsection{Visbemonsteringen en vogeltellingen vanaf het water}

Visstandbemonsteringen zijn vanaf een vissersschip (HK61) uitgevoerd met behulp van een broedkor (fijnmazig sleepnet met breedte van 3 meter, geschikt voor het vangen van kleine vis, "visbroed"), waarbij zowel bodemtrekken als oppervlaktetrekken en in dieper water (>3 m) ook halverwege de waterkolom trekken zijn gedaan (Tabel 1 ). Deze methode is vergelijkbaar met onderzoek uitgevoerd in 2002 en 2003 door De Leeuw en Tulp (2004) voor een vergelijkbaar doel, namelijk onderzoek naar de beschikbaarheid van spiering voor zwarte sterns tijdens de ruiperiode in augustus. Er is in drie perioden van 2-3 dagen bemonsterd in zowel het zuidwestelijk IJsselmeer (8-11 locaties per periode) als oostelijk Markermeer (6-10 locaties per periode). Per locatie werden 2-3 trekken uitgevoerd. Op alle locaties werd tenminste een oppervlaktetrek uitgevoerd en zo mogelijk een bodemtrek (tenzij een bodemprofiel met sterke diepteverschillen dit niet toeliet) en een middentrek (bij diepten $>3 \mathrm{~m}$ ). De locatiekeuze was niet exact van tevoren vastgelegd, maar de bemonsteringslocaties zijn verspreid binnen hetzelfde gebied als waar de vliegtuigtellingen werden uitgevoerd (Figuur 1), doch varieerden deze afhankelijk van de omstandigheden. Wanneer groepen foeragerende sterns werden waargenomen, werd specifiek op die locatie gevist. In het IJsselmeer werd daardoor voorkomen dat in de beperkte tijd die voor deze bemonstering beschikbaar was veel tijd verloren zou gaan aan vistrekken zonder vangst (nulvangsten), terwijl onvoldoende beeld zou ontstaan van de omstandigheden die foeragerende sterns aantrokken. In het Markermeer werden vrijwel geen concentraties foeragerende sterns aangetroffen en werd grotendeels volgens schema gevist. De duur van elke trek was in principe 10 minuten waarbij 600-900 meter werd afgelegd. Deze afstand was afhankelijk van de vaarsnelheid die iets varieerde tussen oppervlakte- en bodemtrekken. Enkele malen werd met name een oppervlaktetrek enkele minuten verlengd wanneer het traject door een groep foeragerende sterns kon worden gestuurd. Op deze wijze werd zoveel mogelijk variatie in omstandigheden (doorzicht, diepte, ruimtelijke verdeling) en in aan- of afwezigheid van sterns bemonsterd.

\section{Tabel 1. Schema visstandbemonstering en vogeltellingen vanaf vissersschip HK61.}

\begin{tabular}{|c|c|c|c|c|c|c|}
\hline Periode & Meer & $\begin{array}{l}\text { Water } \\
\text { temperatuur }\end{array}$ & $\begin{array}{l}\text { Wind } \\
\text { (Bft) }\end{array}$ & $\begin{array}{l}\text { Doorzicht } \\
(\text { Secchi, m) }\end{array}$ & $\begin{array}{l}\text { Aantal } \\
\text { locaties }\end{array}$ & $\begin{array}{l}\text { Aantal trekken } \\
\text { (oppervlak, midden, bodem) }\end{array}$ \\
\hline \multirow[t]{2}{*}{ I. 8-9 juli } & IJsselmeer & 18 & $0-Z O, 1-2$ & 1.9 & 8 & $21(8,5,8)$ \\
\hline & Markermeer & 17 & W, 3-4 & 0.3 & 6 & $18(6,6,6)$ \\
\hline II. $13-17$ juli & IJsselmeer & $19-20$ & $W-Z W, 1-2$ & $1.5-1.6$ & 11 & $29(11,8,10)$ \\
\hline III. $21-23$ juli & Markermeer & $19-20$ & $\mathrm{~N}-\mathrm{NW}, 2-3$ & $0.8-0.9$ & 10 & $29(10,10,9)$ \\
\hline totaal & & & & & 56 & $154(56,49,49)$ \\
\hline
\end{tabular}




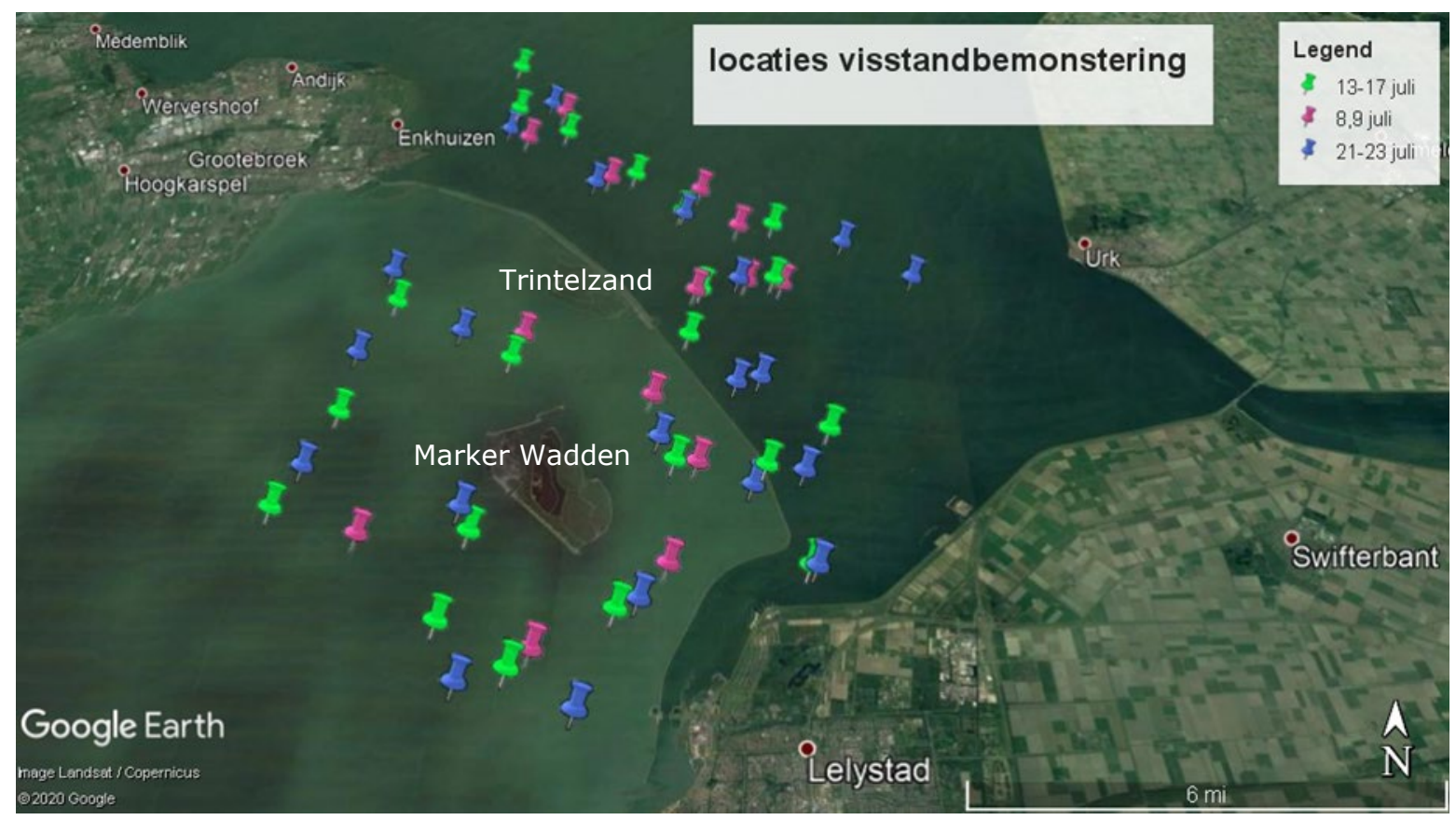

Figuur 1. Locaties van visstandbemonseringen gedurende de 3 bemonsteringsperioden. Op Marker Wadden en Trintelzand bevinden zich broedkolonies visdieven.

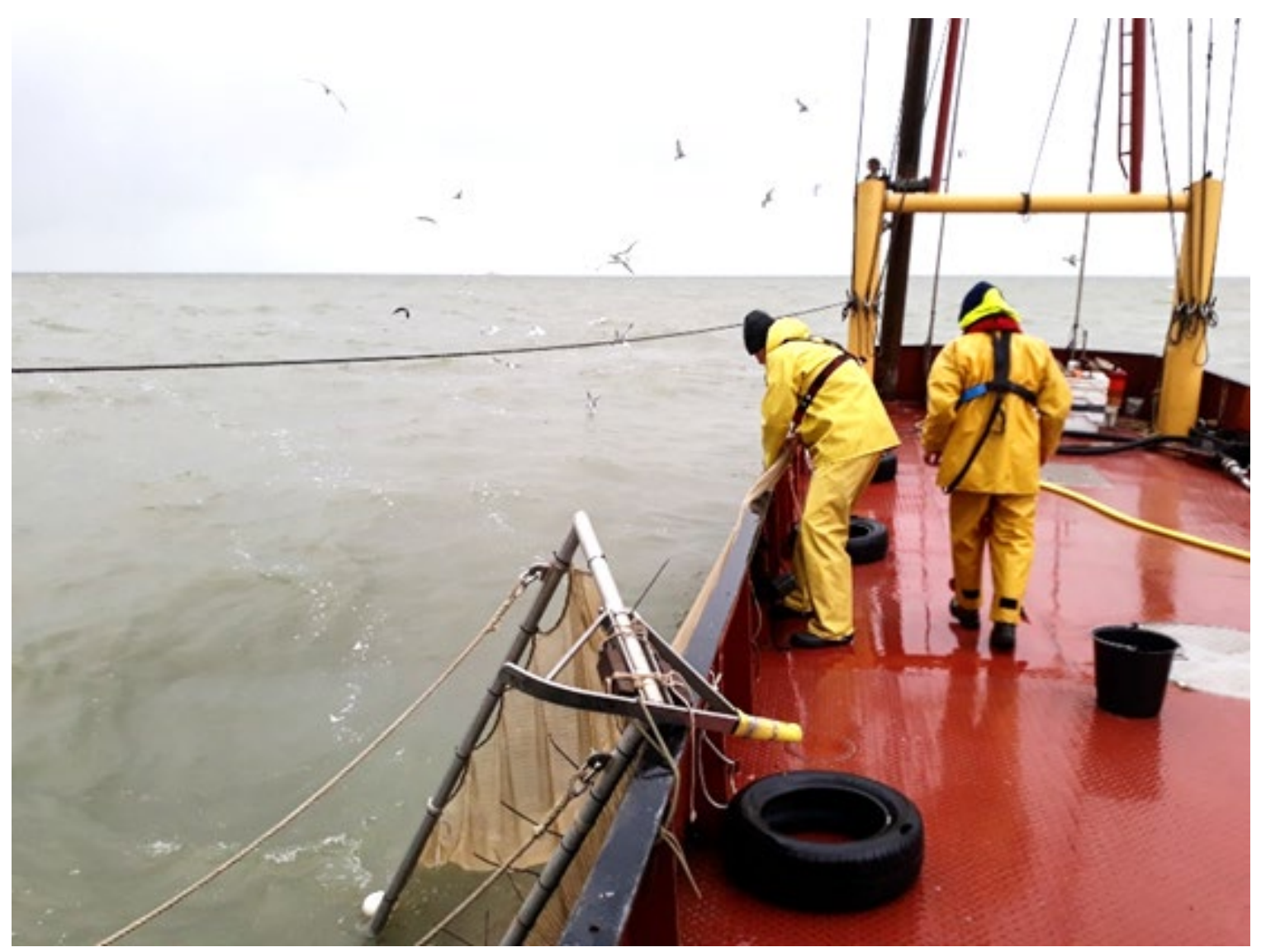

Afbeelding 4 Visbemonstering met broedkor (foto: Joep de Leeuw) 


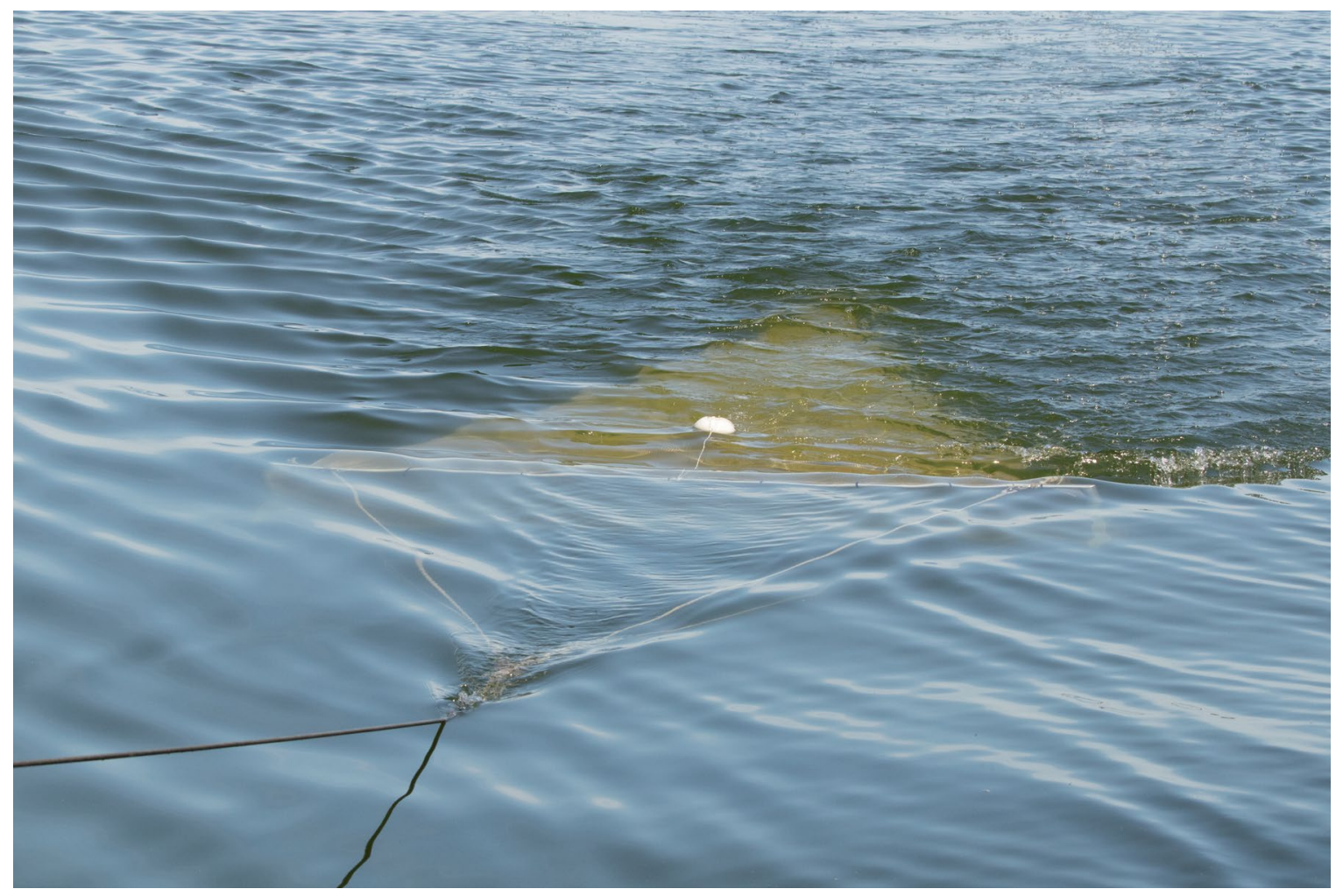

Afbeelding 5 Visbemonstering met broedkor aan het wateroppervlak (foto: Joep de Leeuw)

De vangsten werden aan dek gesorteerd op soort en aantallen en lengteverdelingen van de gevangen soorten werden bepaald. Aanvullend werd informatie verzameld over helderheid (Secchi disc), watertemperatuur (oppervlak), windrichting en windkracht en informatie over de trek (duur, positie begin en eind van de trek, afgelegde afstand op basis van GPS, waterdiepte). Deze gegevens zijn ingevoerd in het databeheerssysteem van WMR met daarop aangepaste routines voor kwaliteitscontrole en dataopwerking.

Tijdens de visstandbemonsteringen werden ook zoveel mogelijk directe waarnemingen van foeragerende visdieven in kaart gebracht die de link tussen visdieven en beschikbare prooivisbestanden kunnen versterken. Daarbij werd onderscheid gemaakt tussen het aantal visdieven dat foerageerde in de nabije omgeving (tot enkele honderden meters vanaf het schip), het aantal visdieven dat langs vloog (foerageervlucht van en naar de broedkolonies) en het aantal visdieven dat eventueel het visserschip volgde. Daarnaast werden ook aantallen andere visetende watervogels genoteerd, met name aantallen zwarte sterns, kokmeeuwen en duikende watervogels als aalscholvers en futen. Wanneer de tijd dat toeliet werden ook foto's gemaakt van visdieven met prooien. 


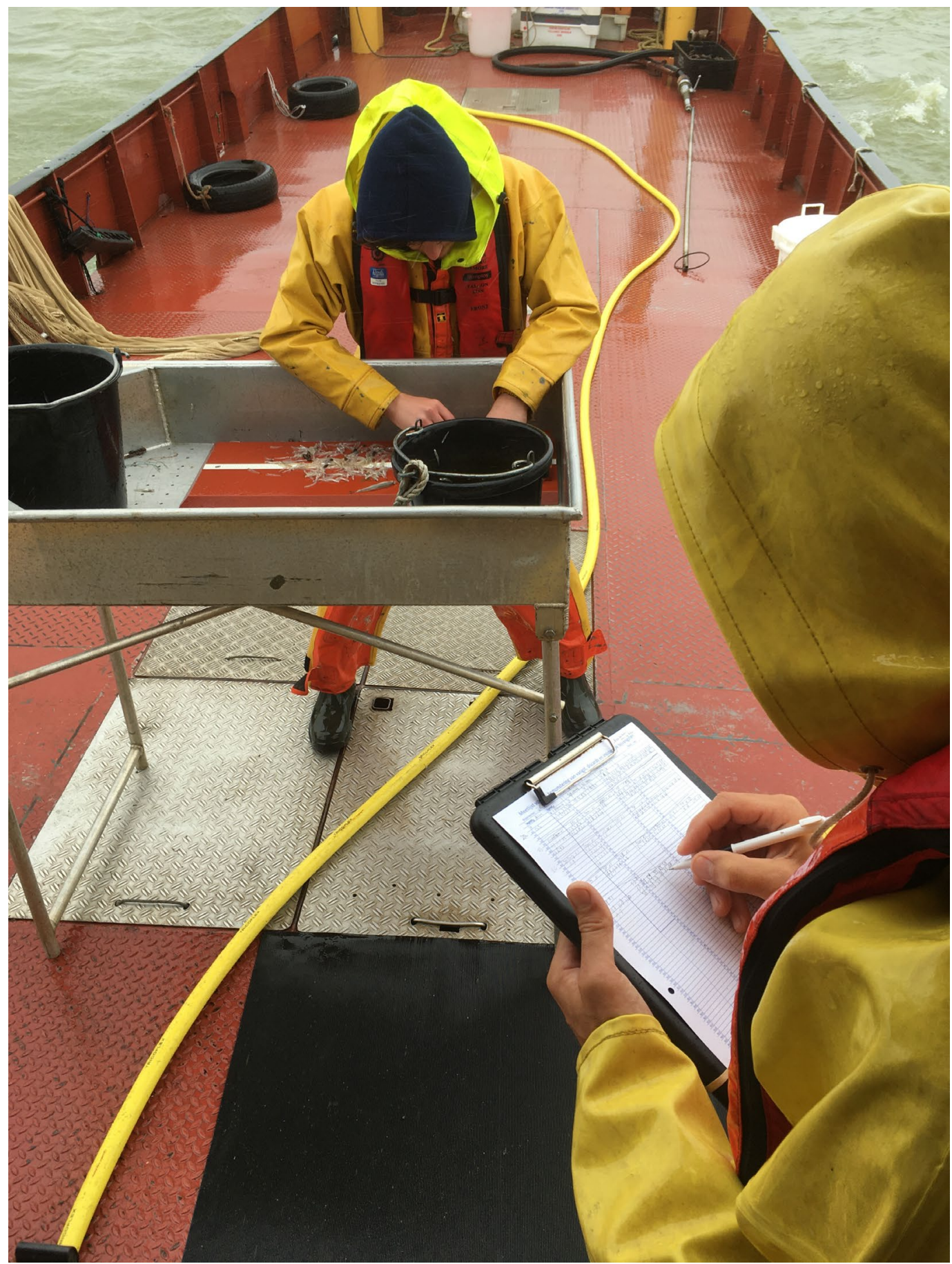

Afbeelding 6 Doormeten van de vangst aan boord (foto: Joep de Leeuw). 


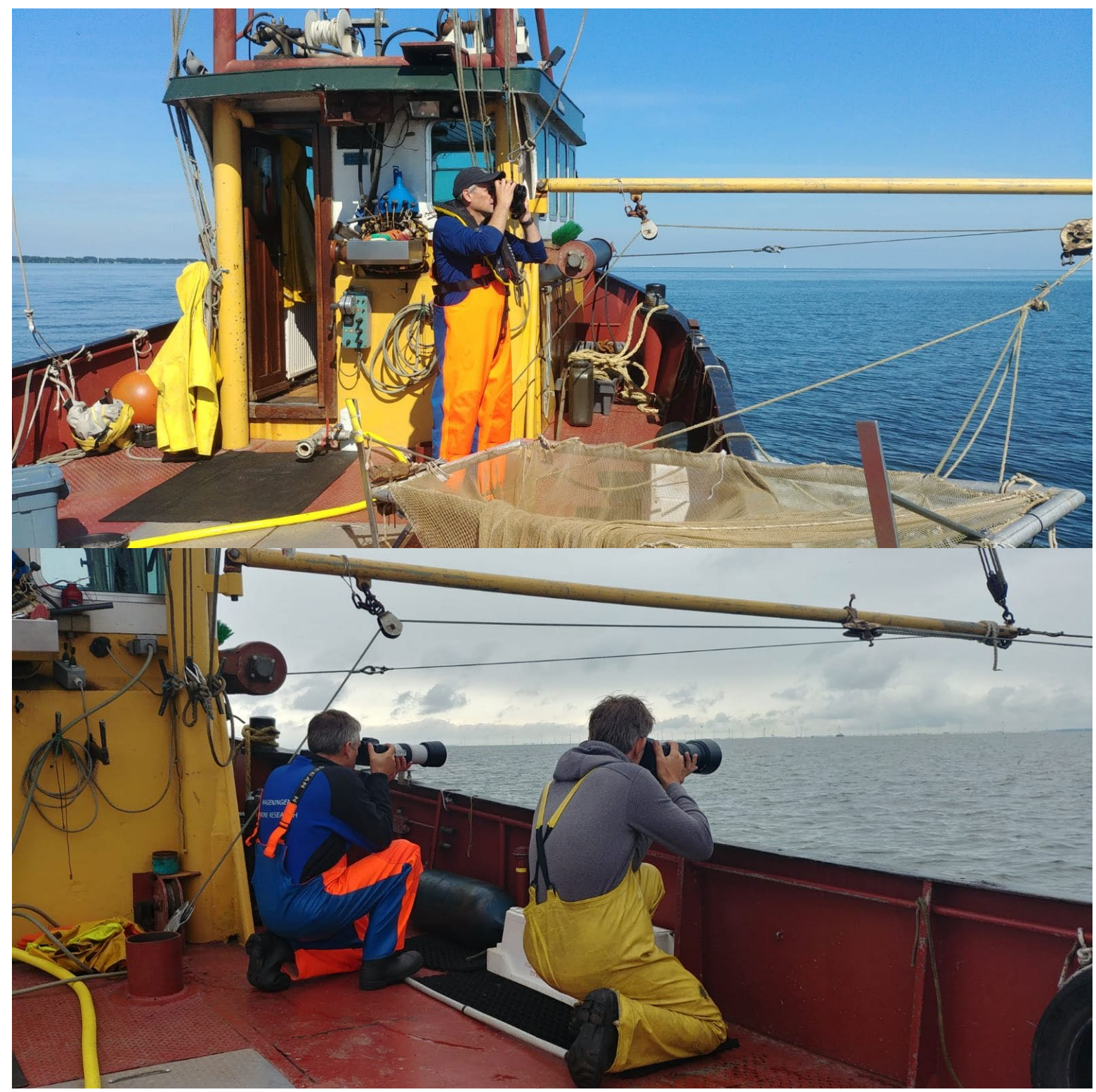

Afbeelding 7 Aantallen foeragerende visdieven werden geteld tijdens elke trek en zo mogelijk werden foto's van foeragerende sterns gemaakt om de voedselkeuze vast te stellen (foto's: Cees Meeldijk) 


\section{Resultaten}

\subsection{Helder/troebel water}
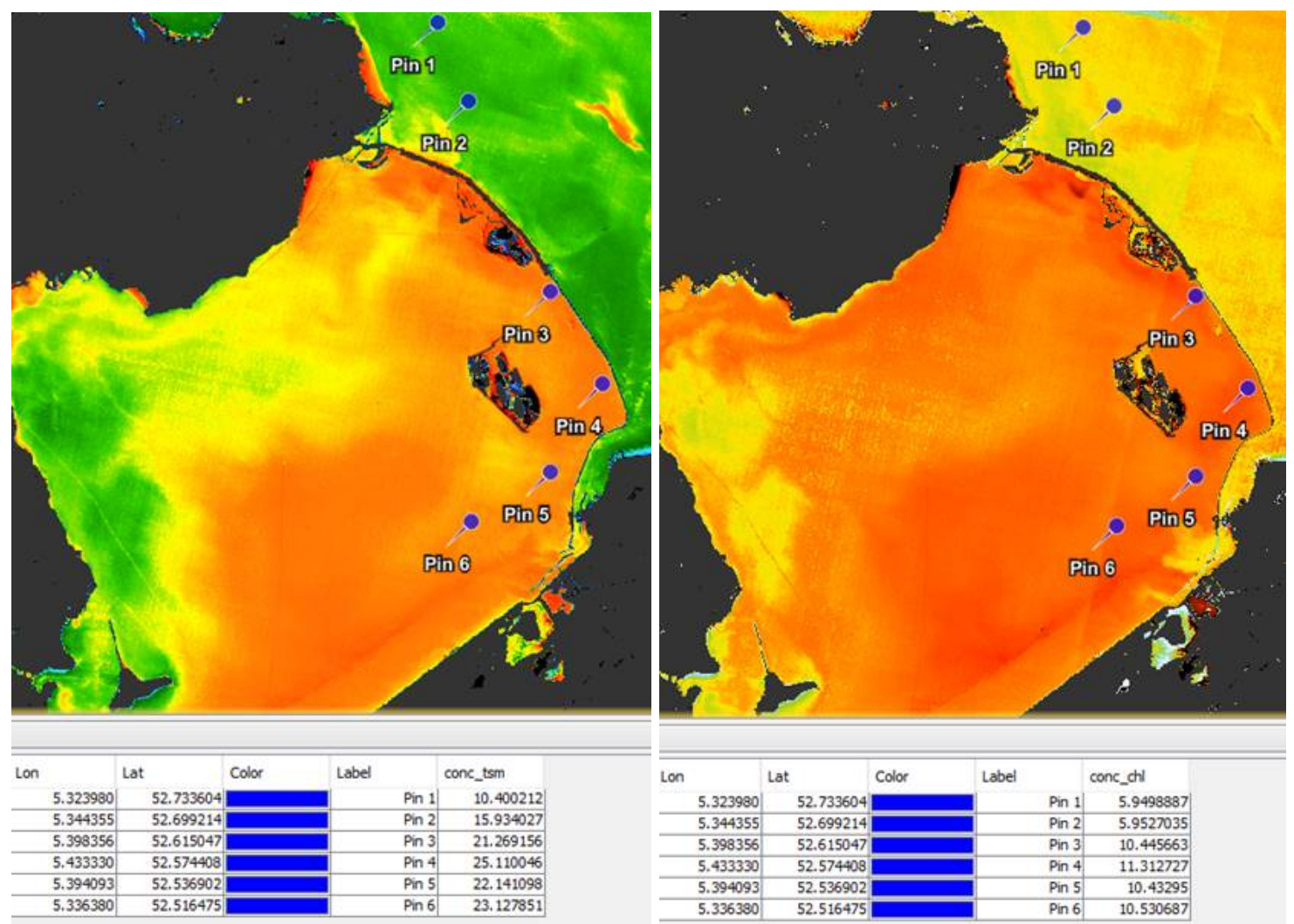

Figuur 2 Satellietbeelden van Markermeer en zuidwestelijk IJsselmeer 31 juli 2020. Links concentratie zwevend stof, rechts concentratie chlorofyl. Pins geven de geschatte waarden in de tabel onder de satellietbeelden (databewerking: Miguel Dionisio Pires, Deltares).

Om een ruimtelijk beeld te geven van de verschillen in helderheid is gebruik gemaakt van satellietbeelden van ESA (European Space Agency) via Miguel Dionisio Pires (Deltares). Vanwege bewolking waren er geen satellietbeelden beschikbaar in de periode van tellingen van het vliegtuig en de visbemonsteringen (8-23 juli), maar waren er wel bruikbare beelden van 31 juli 2020, Figuur 2. Groene-gele kleuren geven heldere situaties aan (lage concentraties zwevend stof, respectievelijk chlorofyl) en oranje-rode kleuren troebele situaties (hoge concentraties zwevend stof en chlorofyl). Als we ervan uitgaan dat de situatie 31 juli niet sterk verschilde van de weken ervoor, illustreren de satellietbeelden dat het Markermeer rond Marker Wadden relatief troebel was en het IJsselmeer helder, vooral het zuidelijk gedeelte ten oosten van de Houtribdijk en ten zuiden van Enkhuizerzand/Trintelhaven. Dit komt overeen met de metingen verricht aan boord tijdens de visstandbemonsteringen (Tabel 1, Figuur 3). Op dagen met een krachtiger wind was het doorzicht lager dan op dagen met rustiger weer (Figuur 3 ). 


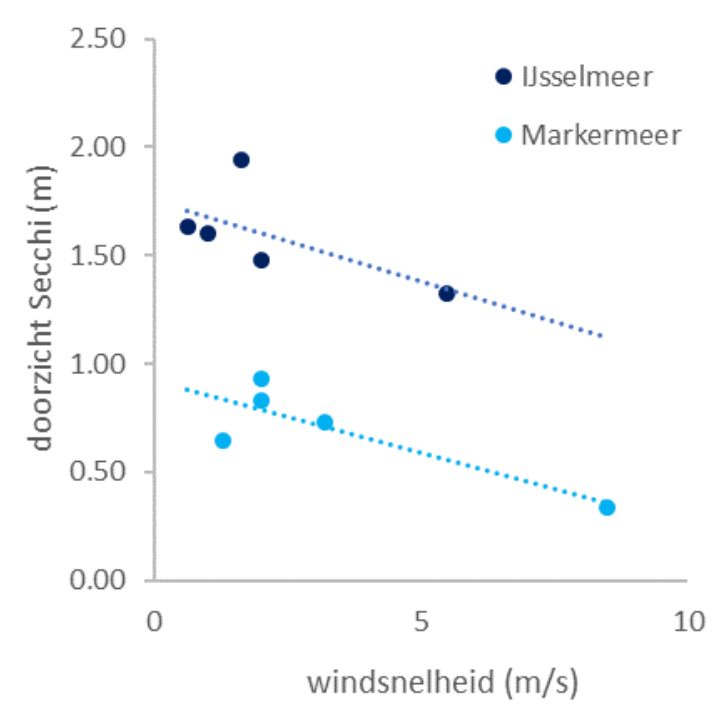

Figuur 3. Relatie tussen doorzicht en windsnelheid in het IJsselmeer en Markermeer gedurende de visstandbemonteringen (daggemiddelden). 


\subsection{Verspreiding van foeragerende visdieven op basis van tellingen vanuit vliegtuig}

De tellingen vanuit het vliegtuig geven een gedetailleerd beeld van de verspreiding en (foerageer)activiteit van visdieven (Figuur 4a-c).

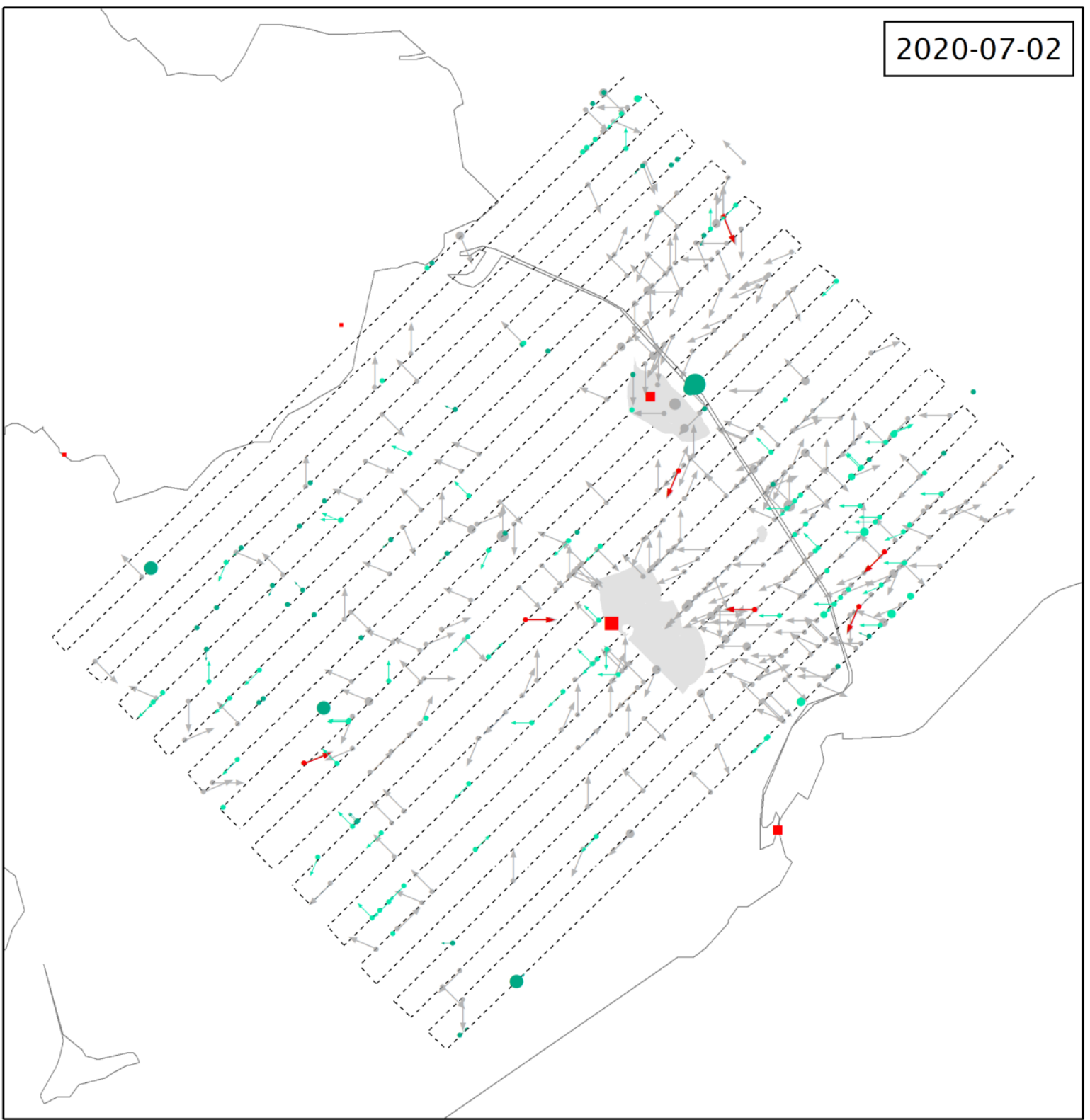

Figur 4a Verspreiding en activiteit van visdieven op basis van telling vanuit een vliegtuig op 2 juli 2020. Overheersende windrichting zuidwest. Groene stippen: foeragerend, pijlen: vliegend, rode vierkanten: broedkolonies op Marker Wadden en Trintelzand. Bron: Poot et al. 2020. 


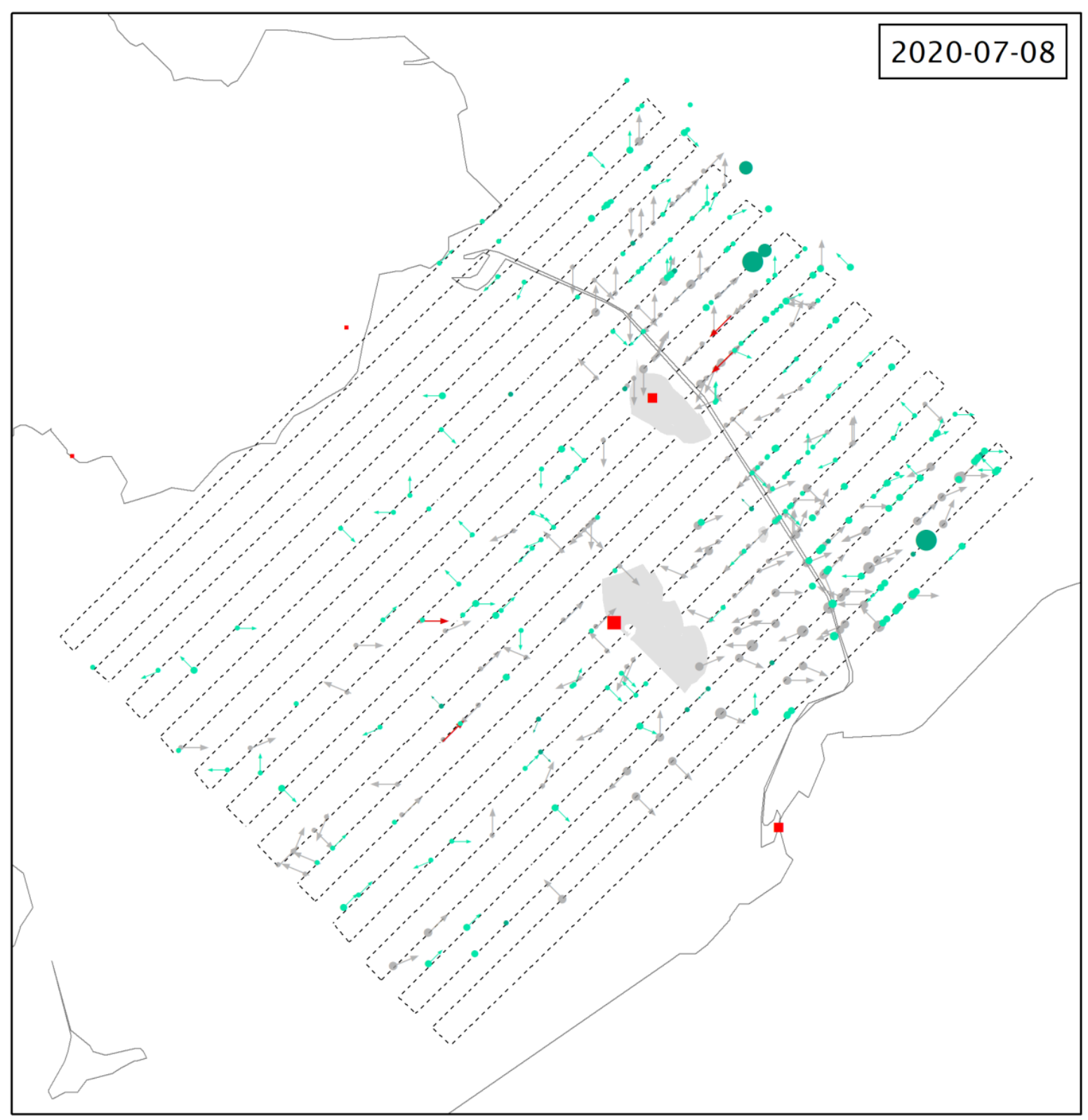

Figur $4 \boldsymbol{b} \quad$ Verspreiding en activiteit van visdieven op basis van telling vanuit een vliegtuig op 8 juli 2020. Overheersende windrichting zuid. Groene stippen: foeragerend, pijlen: vliegend, rode vierkanten: broedkolonies op Marker Wadden en Trintelzand. Bron: Poot et al. 2020. 


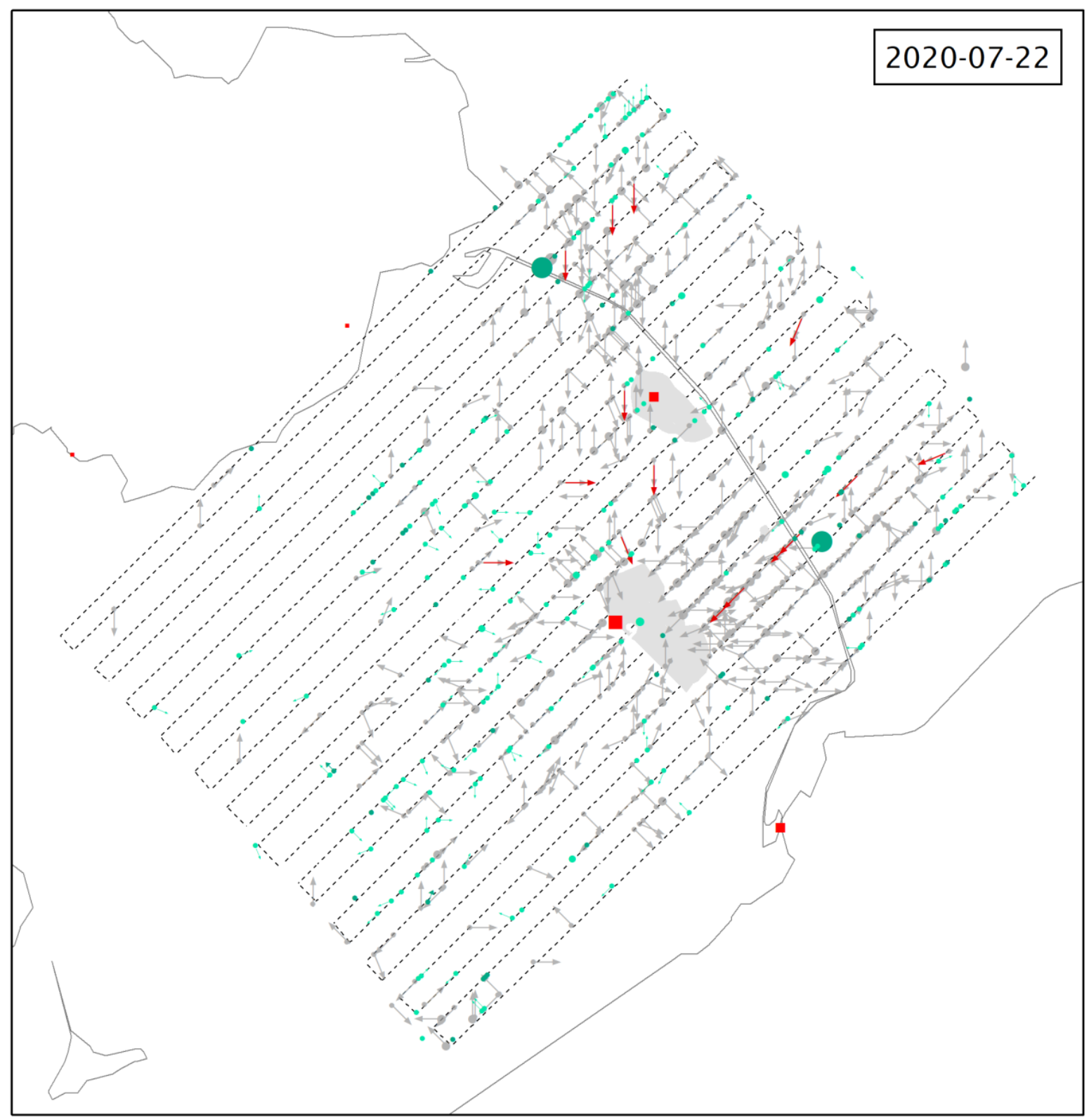

Figuur 4c Verspreiding en activiteit van visdieven op basis van telling vanuit een vliegtuig op 22 juli 2020. Overheersende windrichting noordwest. Groene stippen: foeragerend, pijlen: vliegend, rode vierkanten: broedkolonies op Marker Wadden en Trintelzand. Bron: Poot et al. 2020. 

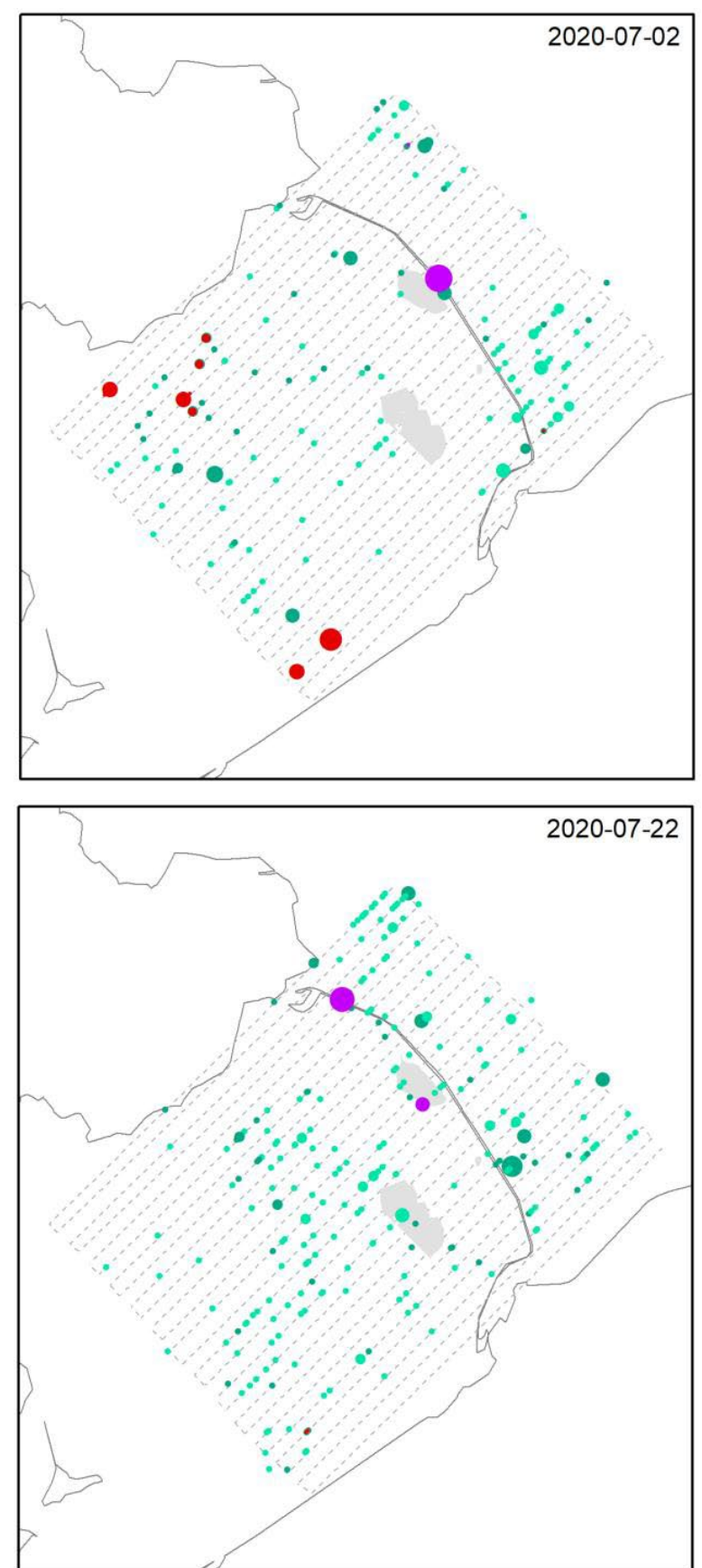

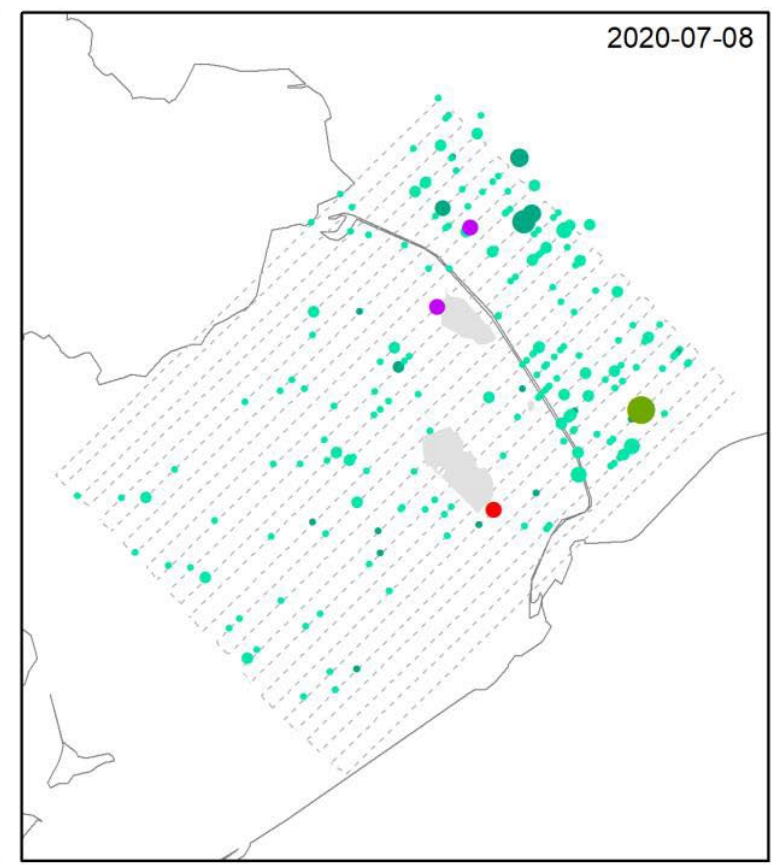

- achter vrachtschip

- bij aalscholvers

- bij vissersschip

- naar vis duikend

- zoekend

Figuur 5. Verspreiding en activiteit van visdieven op basis van warnemingen vanuit een vliegtuig, met waargenomen associaties met foeragerende aalscholvers, vissersschepen en vrachtschepen. Overheersende windrichting ZW (2/7), Z (8/7), NW (22/7). Bron: Poot et al. 2020. 


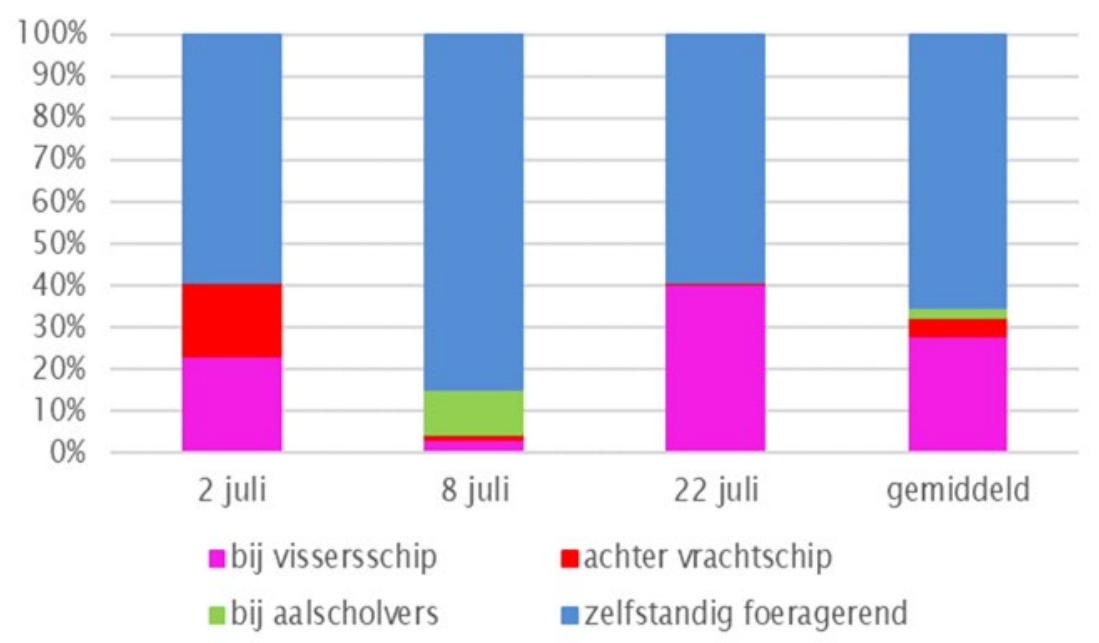

Figuur 6. $\quad$ Fracties zelfstandig en in associatie met aalscholvers of schepen foeragerende visdieven (bron: Poot et al. 2020).

De tellingen vanuit het vliegtuig laten zien dat visdieven op het Markermeer meestal verspreid foerageren in kleine aantallen met een groepsgrootte van hooguit enkele visdieven. Soms worden vrachtschepen gevolgd (Figuur 4 en 5).

In het IJsselmeer werd een meer geclusterd voorkomen genoteerd, waarbij vooral grotere aantallen gezamenlijk foeragerend werden waargenomen, in enkele gevallen in associatie met aalscholvers of in de buurt van vissersschepen, dat wil zeggen vissers die aalfuiken legen.

Over het IJsselmeer en Markermeer samen werd ruwweg 30\% van de visdieven geteld bij (vissers)schepen (Fig. 6). 


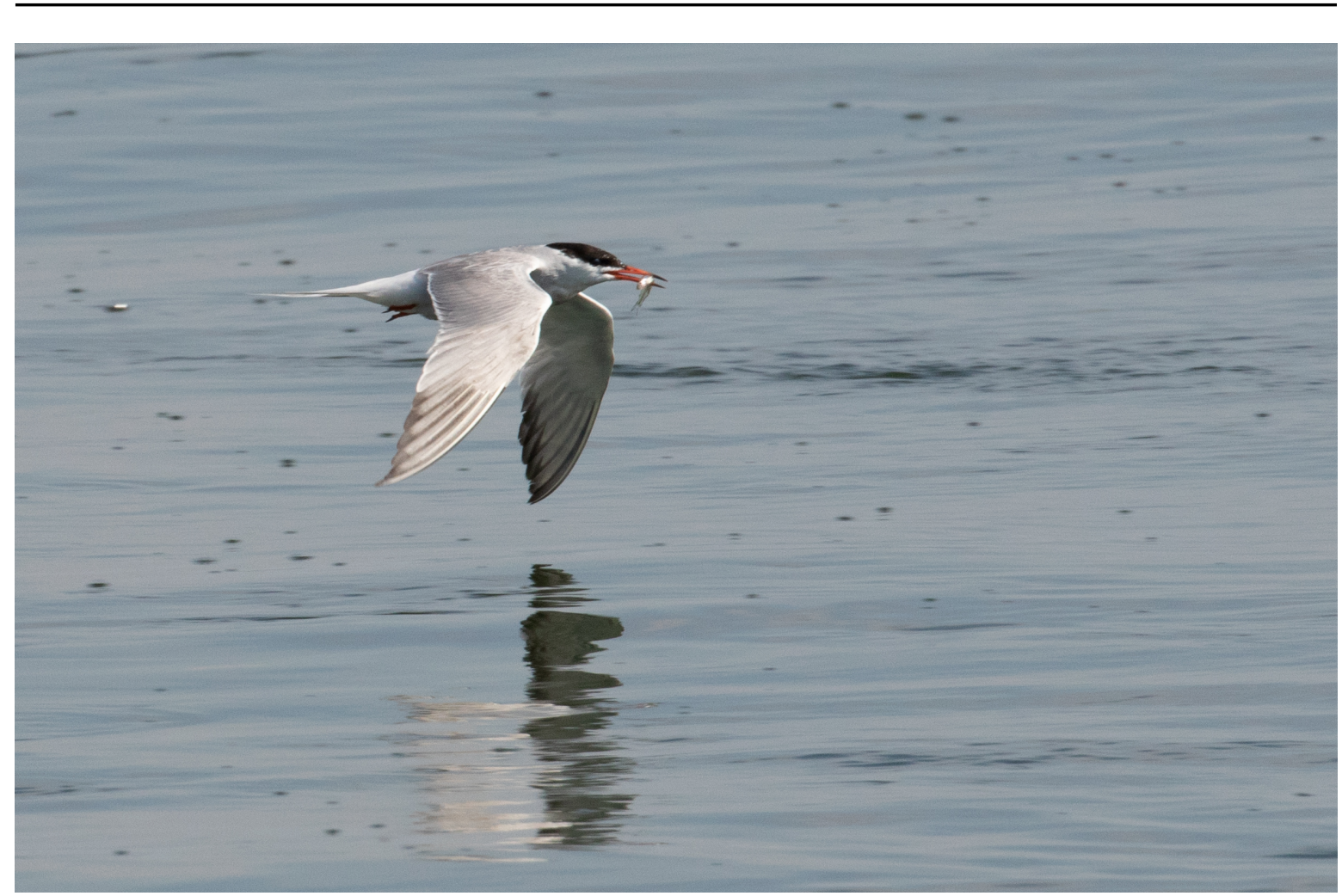

Afbeelding 8 Visdief met spiering vliegend richting broedkolonie (foto: Joep de Leeuw) 


\subsection{Verticale verspreiding prooivis}

De ruimtelijke verspreiding van kleine, (potentiele prooi-)vis varieerde aanzienlijk. Er werden met name verschillen in soortsamenstelling en dichtheden gevonden tussen IJsselmeer en Markermeer. In het vervolg worden beide meren daarom steeds apart besproken. Verschillen binnen meren waren vooral afhankelijk van het voorkomen van foeragerende vogels, en vissersschepen, en de beperkte ruimtelijke dekking en beperkte variatie in helderheid binnen de meren stonden geen verdere ruimtelijke uitsplitsing toe (maar zie effecten van helderheid op voorkomen van vis en vogels verderop).

Een belangrijk aspect van de ruimtelijke verspreiding van prooivis is of deze ook voorkomt aan het oppervlak en daardoor in principe beschikbaar voor foeragerende visdieven. Daarom zijn de soortsamenstelling aan het oppervlak, halverwege de waterkolom en bij de bodem gemiddeld voor IJsselmeer en Markermeer bekeken. Het is goed hierbij op te merken dat de vangstefficiëntie van een broedkor in helder water aan het oppervlak waarschijnlijk lager is dan in troebeler water en in diepere (donkerder) waterlagen omdat het net aan het oppervlak beter zichtbaar is waardoor vis een grotere kans heeft voor het net weg te vluchten.

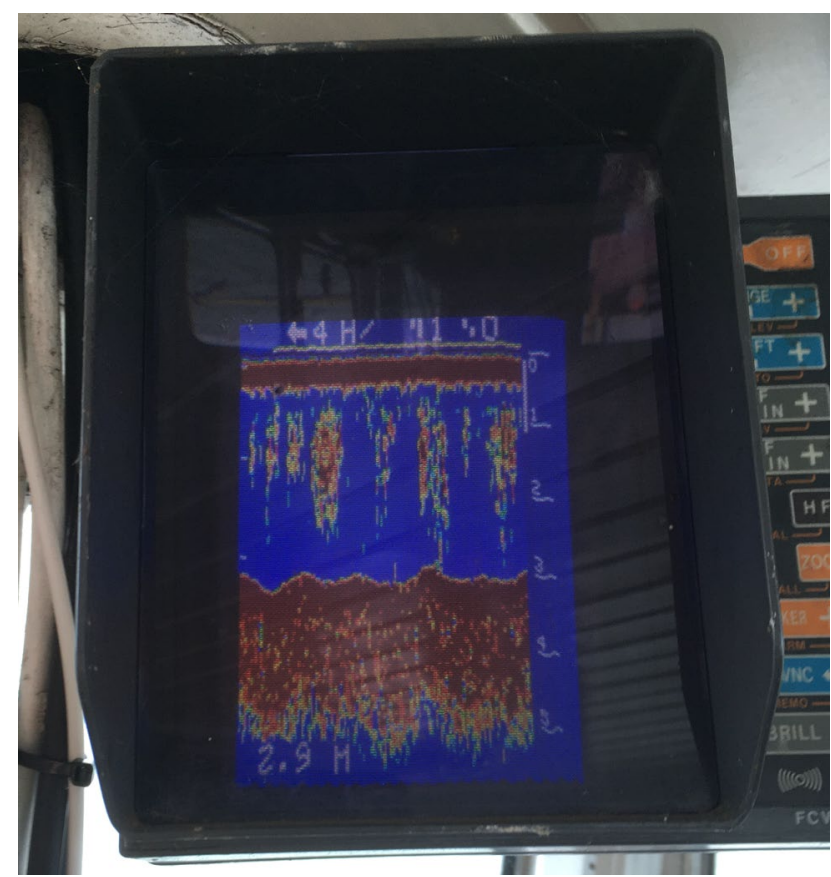

Afbeelding 9 Verspreiding van spiering in vrij losse scholen verspreid over de waterkolom bij een waterdiepte van circa $4 \mathrm{~m}$ (rechterschaal; echosounder van schip op circa $1 \mathrm{~m}$ diepte). Markermeer; 9 juli 2020 (foto: Joep de Leeuw) 

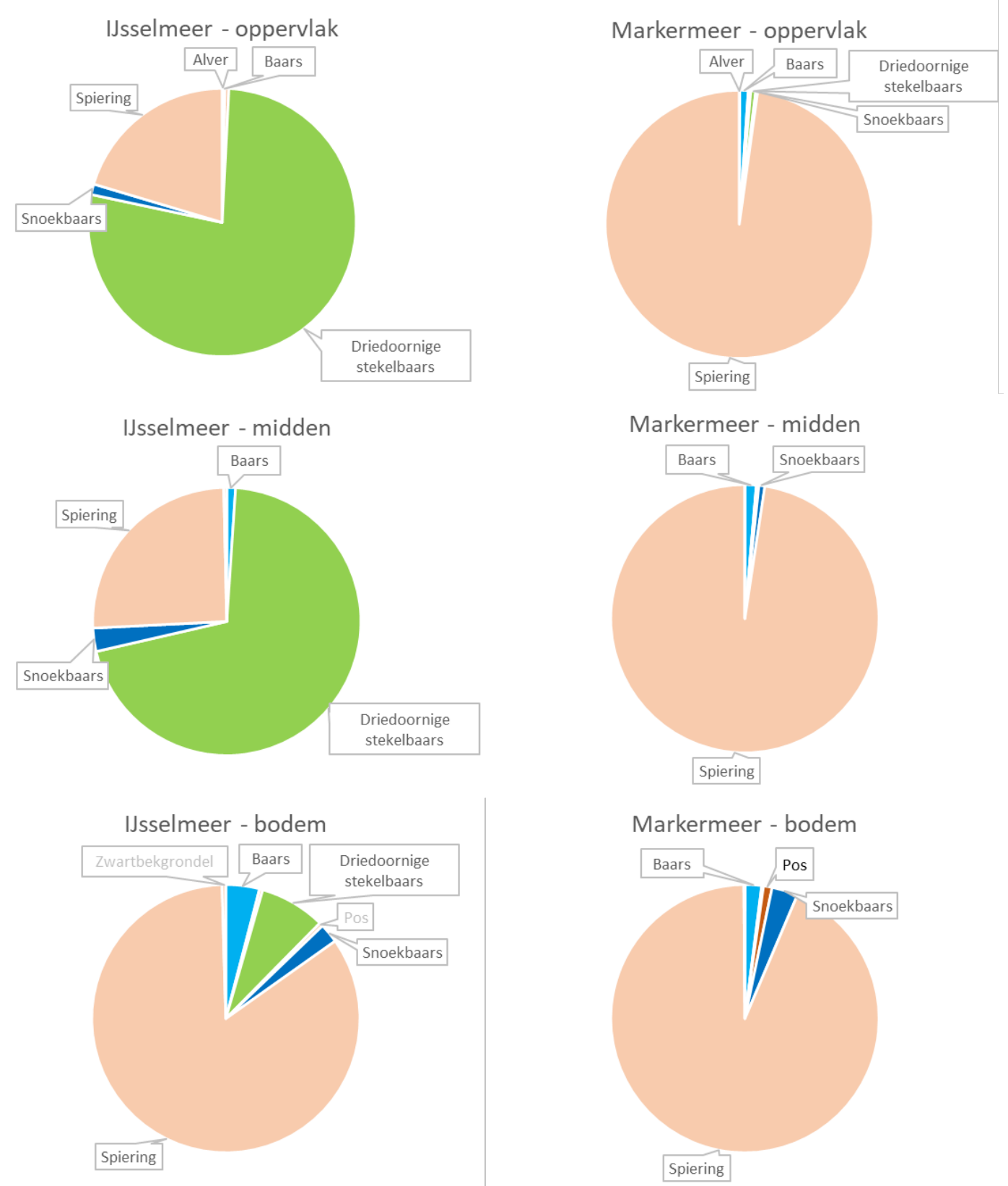

Figuur $7 \quad$ Soortensamenstelling (aantalsfracties) van vangsten met broedkor in IJsselmeer (links) en Markermeer (rechts) aan het oppervlak, midden in de waterkolom, respectievelijk boven de bodem. Gemiddelden per meer en over de 3 bemonsteringsperiodes in juli 2020.

In het IJsselmeer was driedoornige stekelbaars de dominante vissoort (in aantal) in de vangsten aan het oppervlak en halverwege de waterkolom gevolgd door spiering, terwijl spiering de dominante soort was boven de bodem (Figuur 7). In het Markermeer was spiering de talrijkste soort onafhankelijk van waar in de waterkolom. De fractie baars en snoekbaars neemt toe dichter bij de bodem in beide meren. Pos werd alleen bij de bodem aangetroffen, terwijl alver uitsluitend aan het oppervlak werd gevangen. 


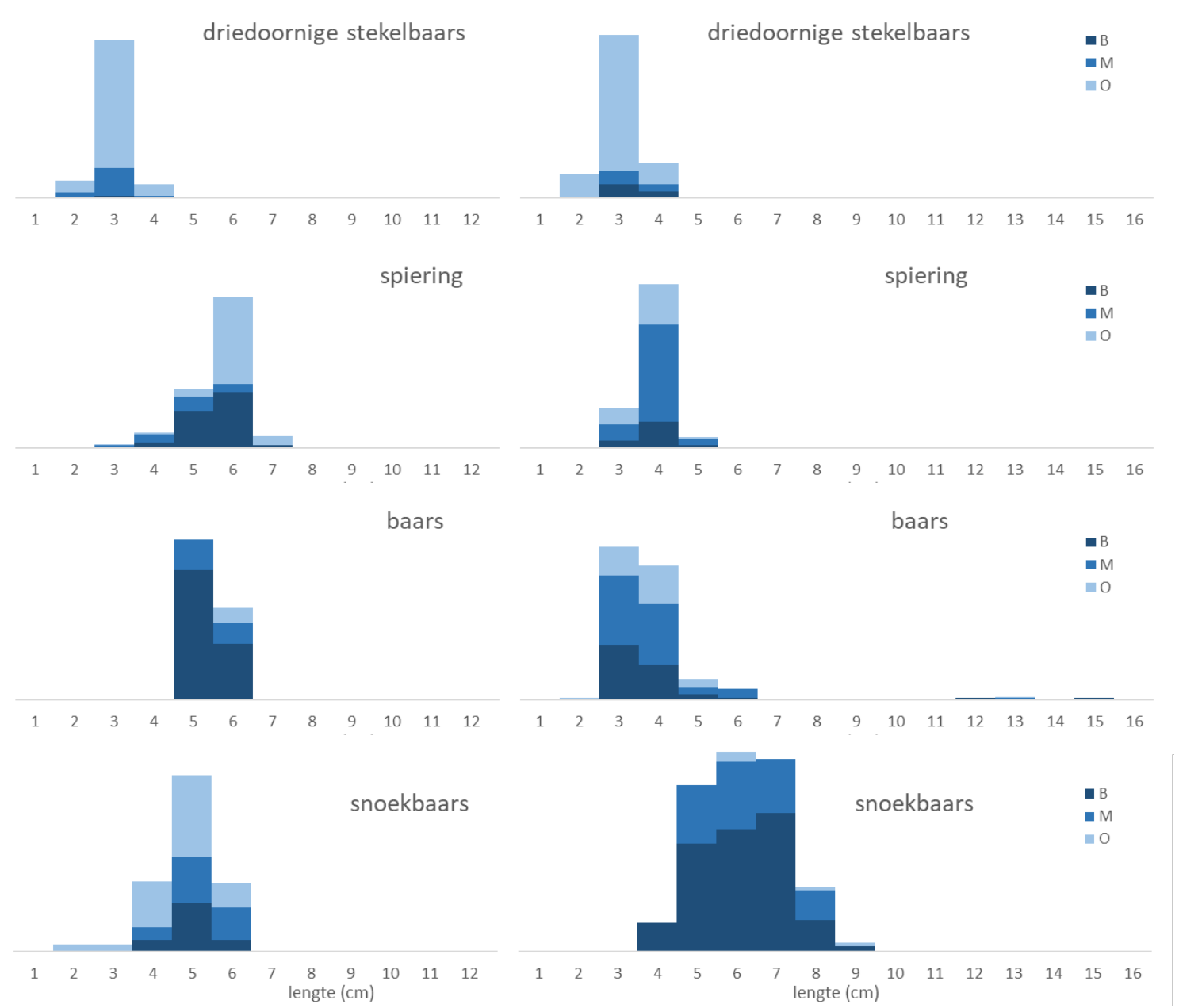

Figur $8 \quad$ Lengtesamenstelling (aantalsfracties) van vangsten met broedkor in IJsselmeer (links) en Markermeer (rechts) aan het oppervlak (O), midden in de waterkolom (M), respectievelijk boven de bodem (B). Gemiddelden per meer en over de 3 bemonsteringsperiodes in juli 2020.

Driedoornige stekelbaars was de kleinste potentiele prooivis in juli met een gemiddelde van $3 \mathrm{~cm}$ in zowel het IJsselmeer als het Markermeer (Figuur 8). Spiering en baars waren groter in het IJsselmeer (5-6 cm) dan in het Markermeer (meeste 3-4 cm). Snoekbaars in het IJsselmeer was echter kleiner (gemiddeld $5 \mathrm{~cm}$ ) en magerder dan in het Markermeer (gemiddeld 6-7 cm).

De lengteverdeling per soort was min of meer hetzelfde over de waterkolom (oppervlakte, midden en bodem) in beide meren.

\subsection{Aantallen en gedrag van visdieven bij visbemonsteringslocaties}

De aantallen foeragerende visdieven per visbemonsteringslocatie (gemiddeld aantal waargenomen bij oppervlakte, midden en bodemtrek per locatie) verschilden sterk (Figuur 9). Op een kwart van de bemonsteringslocaties werden geen visdieven foeragerend waargenomen. In het Markermeer werden meestal slechts enkele foeragerende sterns gezien, maar in het IJsselmeer werden groepen tot circa 150 foeragerende individuen aangetroffen tijdens de visstandbemonsteringen. Opvallend was dat op locaties met grotere aantallen foeragerende visdieven (ordegrootte 10-100) vaak ook foeragerende aalscholvers of futen werden aangetroffen. 


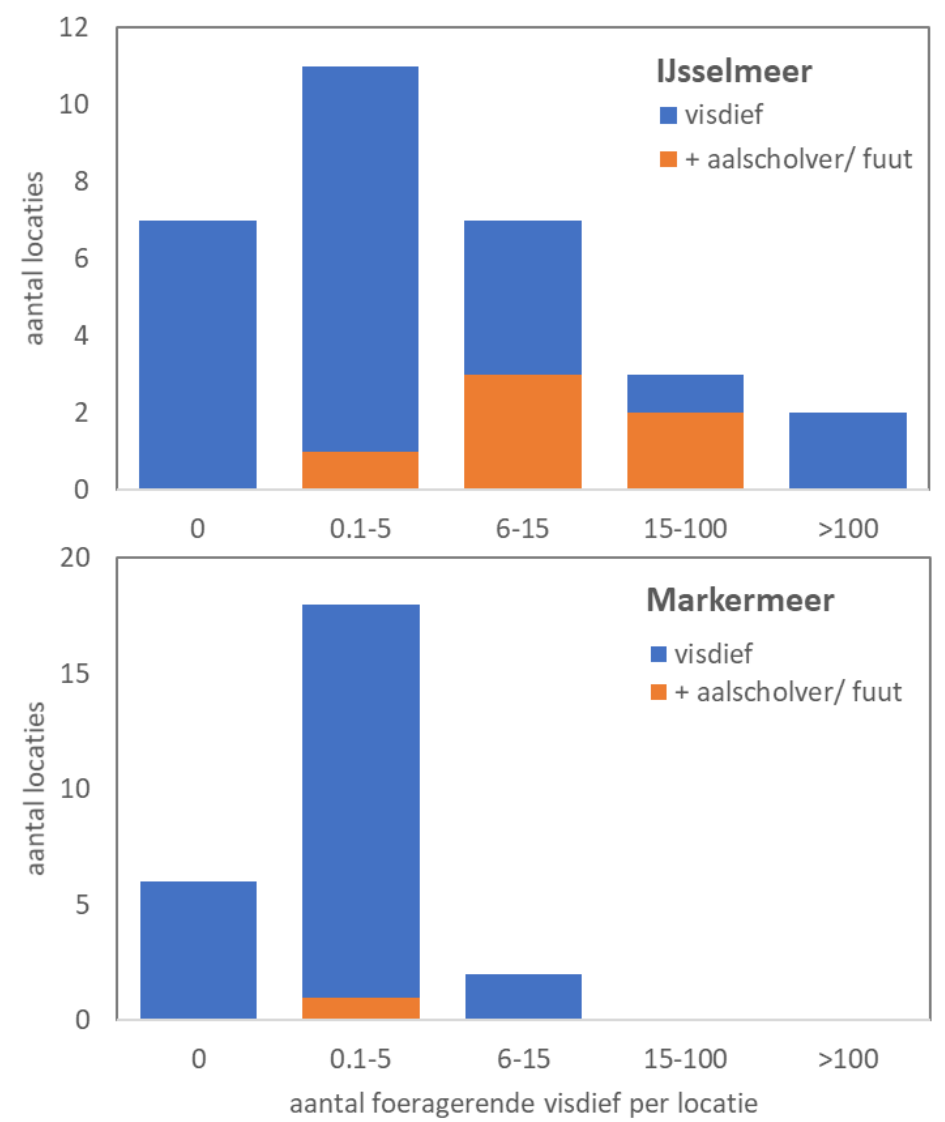

Figur 9 Frequentieverdeling van aantallen foeragerende visdieven per locatie (gemiddelde geteld bij oppervlakte-, midden- en bodemtrek). Locaties waar tevens foeragerende aalscholvers en/of futen werden aangetroffen zijn in oranje aangegeven.

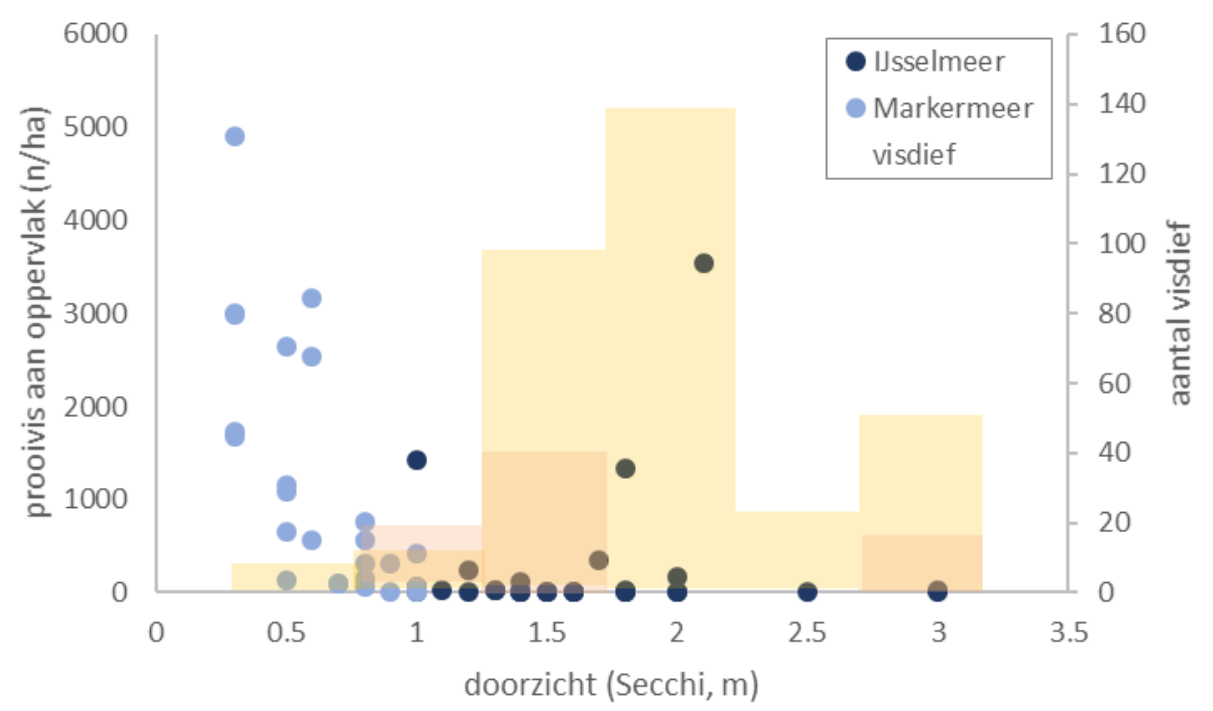

Figuur 10 Abundantie van prooivis aan het oppervlak ( $n /$ ha, blauwe stippen) per locatie en aantal waargenomen visdieven (histogram) in relatie tot het doorzicht (Secchi, m). Locaties waar tevens foeragerende aalscholvers en/of futen werden aangetroffen zijn in donkerder histogram aangegeven.

Door wisselende windrichting en windkracht op de verschillende bemonsteringsdagen was er verschil in doorzicht ook binnen de meren (Fig. 3). In het Markermeer varieerde het doorzicht tussen locaties van $0.25-1.0 \mathrm{~m}$ Secchi, in het IJsselmeer van $1.0-3.0 \mathrm{~m}$. In het Markermeer nam de vangkans (aantallen vis gevangen met de broedkor) aan het oppervlak duidelijk af met toenemend doorzicht (Figuur 10). In het IJsselmeer was de vangkans van potentiele prooivis beperkt en werden slechts enkele keren grotere hoeveelheden aan het oppervlak aangetroffen bij een doorzicht van 1, resp 1.5- 
$2 \mathrm{~m}$. Bij de hogere dichtheden prooivis aan het oppervlak bij een doorzicht van $1.5-2 \mathrm{~m}$ werden ook grotere aantallen foeragerende visdieven waargenomen. Associaties van foeragerende visdieven met foeragerende aalscholvers en futen werden vooral waargenomen bij een doorzicht van $1-1.5 \mathrm{~m}$ (Figuur 10).

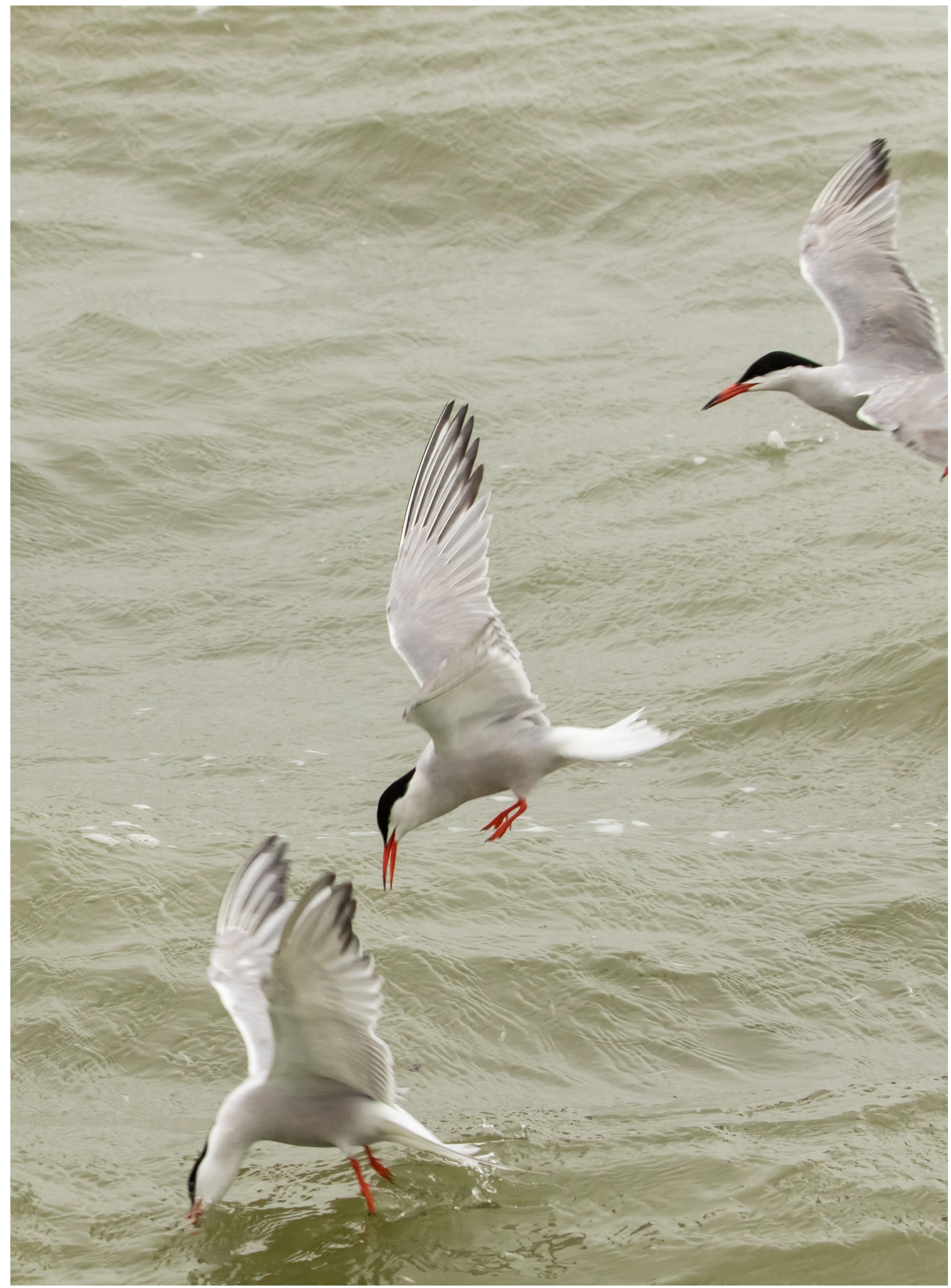

Afbeelding 10 Visdieven foeragerend op kleine spiering in het Markermeer (foto: Joep de Leeuw) 


\subsection{Waargenomen prooikeuze}

Op basis van foto's die zijn genomen tijdens de visstandbemonstering van foeragerende sterns en van sterns die met een prooi richting de broedkolonie vlogen is een eerste indicatie verkregen van de prooikeuze op diverse locaties. De omstandigheden om foto's te kunnen nemen varieerden sterk en deze resultaten moeten als anekdotisch worden beschouwd. Ze weerspiegelen zeker geen representatief beeld van de prooikeuze. De foto's laten echter een duidelijk verschil zien in (1) prooien die op het open water in het IJsselmeer werden bemachtigd, (2) prooien van visdieven die langs de dijk foerageerden in de buurt van aalfuiken die werden geleegd en (3) prooien van visdieven die boven het Markermeer vliegend vanaf het IJsselmeer werden waargenomen, maar waarbij dus geen onderscheid gemaakt kon worden of de prooien in het open water waren bemachtigd of in de buurt van aalfuiken die geleegd werden (Tabel 2). Succesvolle vangsten van visdieven op het Markermeer werden nauwelijks waargenomen en er is geen fotomateriaal beschikbaar van prooikeuze op het Markermeer.

Tabel 2. Prooivis van visdieven gefotografeerd vanaf vissersschip HK61 tijdens de visstandbemonsteringen.

\begin{tabular}{lccc} 
Soort & $\begin{array}{c}\text { open water IJsselmeer } \\
\text { (oost van Houtribdijk) }\end{array}$ & $\begin{array}{c}\text { Houtribdijk IJsselmeer } \\
\text { nabij aalfuiken }\end{array}$ & $\begin{array}{c}\text { Markermeer oost } \\
\text { komend van IJsselmeer }\end{array}$ \\
\hline spiering & 27 & 1 & 3 \\
stekelbaars & 1 & & 3 \\
\hline houting & 1 & 1 & 3 \\
\hline snoekbaars & 3 & 1 & 1 \\
\hline baars/cyprinide & 1 & 2 & \\
\hline pos & & 1 & \\
zwartbekgrondel & & & \\
\hline
\end{tabular}

Op het open water werden vooral visdieven met spiering in de snavel waargenomen. Op foto's van visdieven die met prooien naar de broedkolonie vlogen werd slechts een enkele keer driedoornige stekelbaars waargenomen terwijl die domineert in de (oppervlakte)vangsten in het IJsselmeer. Wel werd waargenomen dat visdieven soms kleine prooien vingen en direct inslikten waar bij ten minste een deel het sterke vermoeden bestaat dat het om stekelbaars ging. Ook werd waargenomen dat visdieven direct naast het schip stekelbaars vingen en direct inslikten wanneer stekelbaars na een bemonstering overboord gezet werd. Deze visdieven bleven daarna vaak nog even rond het schip in afwachting van een andere (grotere) prooi zoals spiering of snoekbaars en vlogen daarmee dan meestal direct richting de broedkolonies. Het is dus mogelijk dat visdieven in het IJsselmeer een aanzienlijke hoeveelheid stekelbaars eten (in overeenstemming met de aanzienlijke hoeveelheden die in oppervlaktetrekken worden gevonden) zonder dat dat goed waarneembaar is maar dat ze door blijven foerageren totdat ze grotere prooien (spiering en snoekbaars) vangen die ze naar de broedkolonies transporteren om de jongen te voeren.

Bij vissersboten die hun aalfuiken leegden werden visdieven waargenomen die ook bodemsoorten als pos en zwartbekgrondel hadden bemachtigd, soorten die zich van nature niet aan het oppervlak begeven. Het is aannemelijk dat het hier gaat om dode bijvangst uit de aalfuiken die aan het oppervlak drijft en daardoor een makkelijke prooi voor visdieven is.

De visdieven die op het Markermeer werden waargenomen terwijl ze aan kwamen vliegen van het IJsselmeer vertoonden een gemengd beeld en betrof hier vermoedelijk zowel vogels die in het open water hadden gefoerageerd als vogels die bijvangst van aalfuiken hadden bemachtigd. 


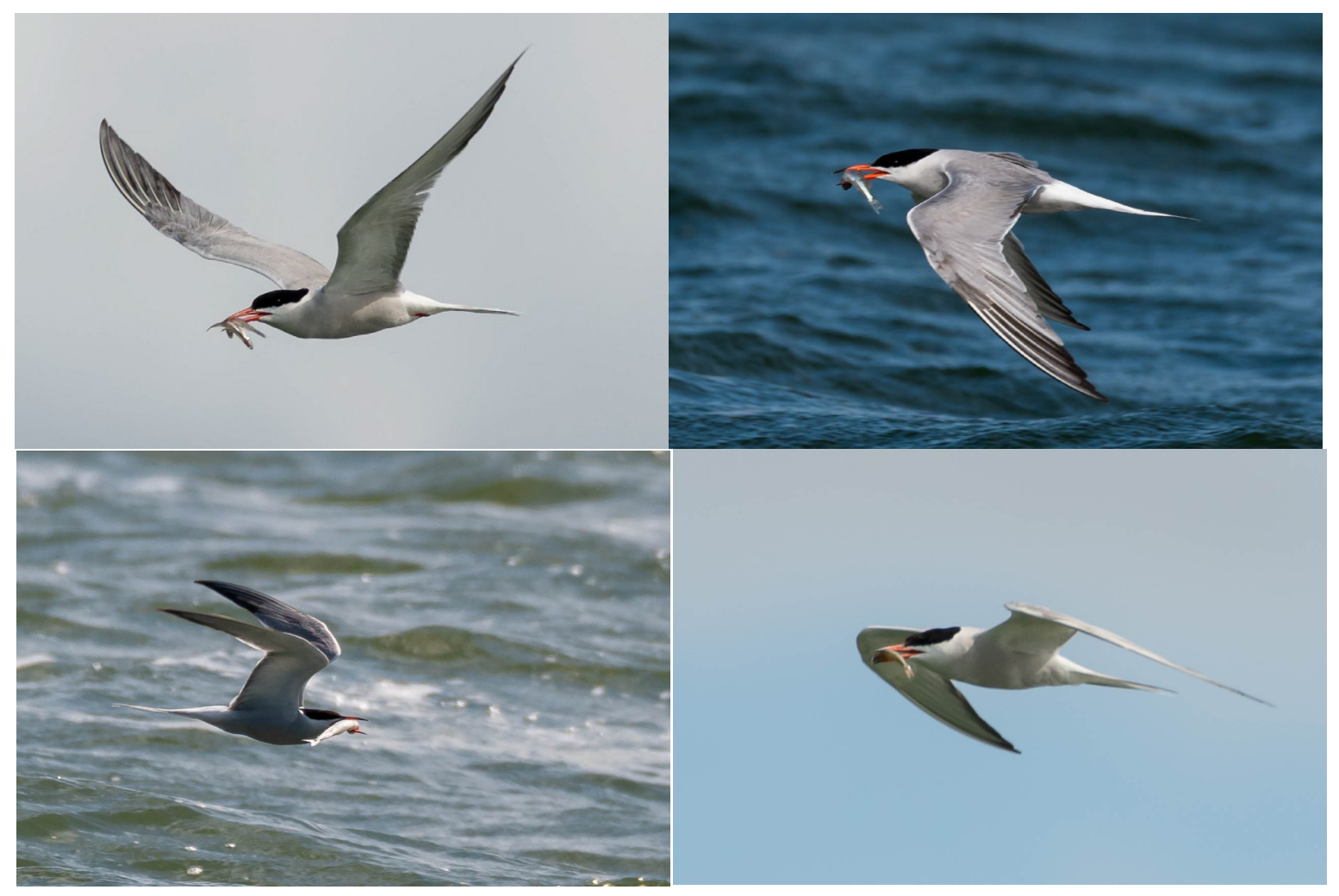

Afbeelding 11 Visdieven met verschillende prooivissen (met de klok mee vanaf linksboven: spiering (x2), snoekbaars, baars, houting) (foto's: Olvin van Keeken) 


\section{Conclusies en aanbevelingen}

\subsection{Ruimtelijke verspreiding foerageergebieden en prooikeuze}

Het IJsselmeer bleek een belangrijk foerageergebied te vormen voor visdieven die broedden op Marker Wadden en Trintelzand in juli 2020. Met een doorzicht van 1-3 m was de kans groot dat vis zich overdag in diepere waterlagen ophield en niet bereikbaar was voor visdieven. Op veel plekken werd weinig tot geen vis gevangen aan het oppervlak en werden geen foeragerende vogels waargenomen. Regelmatig echter kwamen visdieven geclusterd voor in relatief grote groepen tot meer dan 100 visdieven bij elkaar, niet zelden vergezeld van enkele of zelfs tientallen zwarte sterns. Bij dergelijke groepen foeragerende visdieven werden vaak ook aalscholvers (individueel of sociaal foeragerend) en futen (vaak in de buurt van fonteinkruidvelden en langs de dijk) aangetroffen, waarvan aangenomen mag worden dat deze prooivis naar het oppervlak joegen waardoor ze ook beschikbaar kwamen voor visdieven. Ook werden grotere groepen foeragerende visdieven waargenomen, schijnbaar zonder aanwezigheid van duikende vogels. Het is denkbaar dat prooivis ook nadat jagende aalscholvers en futen het gebied al hebben verlaten nog een tijd aan het oppervlak blijven voordat ze weer dieper water opzoeken. Het is echter ook goed mogelijk dat in die gevallen jagende baars of snoekbaars scholen vis naar het oppervlak joeg. De broedkor is zo fijnmazig en gegeven het heldere water zichtbaar in het IJsselmeer overdag dat de vangkans van grotere roofvis zeer laag is. We konden dit in dit onderzoek daarom niet ondersteunen met waarnemingen, maar eerder onderzoek aan de ruimtelijke verdeling van spiering en het voorkomen van zwarte stern leek inderdaad samen te hangen met het voorkomen van roofvis (met name baars) die spiering naar het oppervlak joeg (Tulp \& De Leeuw 2002; De Leeuw \& Tulp 2004).

Effect van wind was lastig te onderzoeken omdat de windcondities snel varieerden tussen dagen en perioden. Door de wisselende windrichting ontstonden geen duidelijke patronen rond Marker Wadden. Ook door het ontbreken van satellietbeelden juist op het moment van bemonsteringen konden geen opmerkelijke patronen zoals bijvoorbeeld baggerpluimen worden waargenomen. Over eventuele effecten van golfwerking en luwte op de foerageermogelijkheden kunnen we met het nu beschikbare datamateriaal daarom weinig zeggen. Wel veranderde de helderheid met de windkracht en daarmee de vangkans. Het is niet duidelijk in hoeverre dit zowel de vangkans (vangstefficiëntie) van de broedkor betreft als de kans dat vis zich in de bovenste waterlagen bevindt en daarmee de vangkans van vis voor visdieven.

In het Markermeer was de verspreiding van prooivis en visdieven meer gelijkmatig zonder grotere concentraties. Er werden nauwelijks visdieven met prooien waargenomen. Vanuit het vliegtuig werd ook een meer verspreid beeld van visdieven waargenomen. Langs vaarroutes werd waargenomen dat visdieven vrachtschepen volgden. Die gebieden lagen grotendeels buiten de visstandbemonsteringen dus we beschikken niet over ondersteunende gegevens van vangsucces en prooikeuze achter vrachtschepen. Vermoedelijk gaat het echter om spiering die in aanzienlijke hoeveelheden werd gevangen tijdens de bemonsteringen en die in het schroefwater van vrachtschepen (mogelijk versuft of dood) naar het oppervlak komen en daar een makkelijke prooi vormen voor visdieven.

Bij de Houtribdijk in de buurt van vissersschepen die bezig waren aalfuiken te legen werden ook regelmatig visdieven aangetroffen (circa 30\% van foeragerende visdieven) met prooien die afwijken van de samenstelling prooivis in het open water doordat ook bodemvis als pos en zwartbekgrondel bereikbaar kwam (Figuur 11). Opvallend is dat pos ook veelvuldig in het dieet van jongen op Marker Wadden voorkomt (Figuur 11; Van der Winden \& Dreef 2020), evenals relatief grote hoeveelheden baars/blankvoorn en snoekbaars. Daarentegen werd nauwelijks spiering gevoerd aan de jongen, hoewel op de locaties waar visdieven sociaal foerageerden spiering de prooikeuze domineerde en visdieven veelvuldig met spiering in de snavel richting de broedkolonies vlogen. 

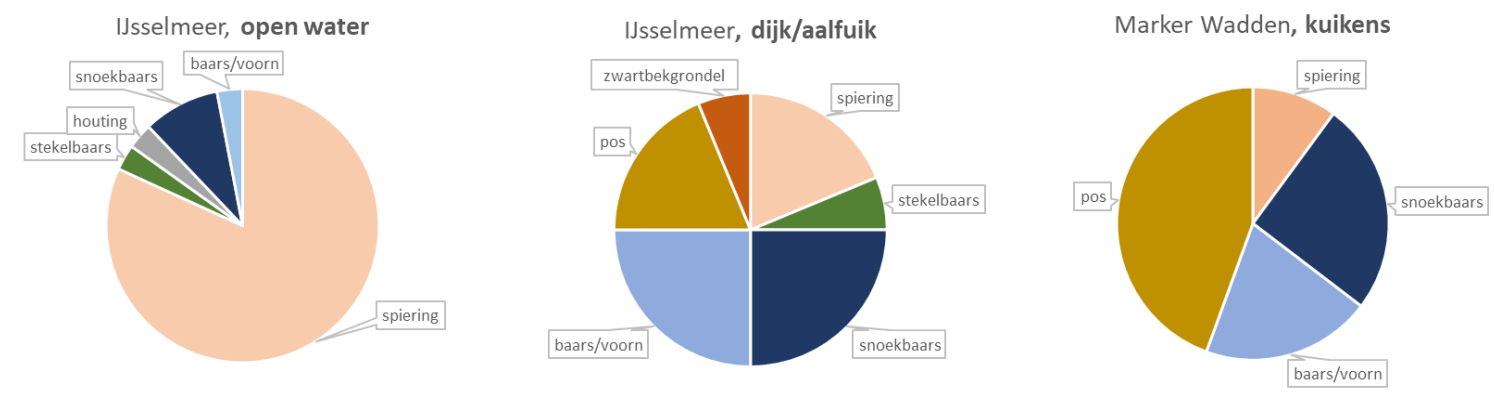

Figuur 11 Prooisamenstelling van visdieven gefotografeerd op (1) het open water van het zuidwestelijk IJsselmeer (Enkhuizen, Trintelzand, Flevocentrale, Houtrib)(n=33), (2) langs de Houtribdijk ten zuiden van Trintelhaven en (op het Markermeer vliegend vanaf IJsselmeer) tussen de Houtribdijk en Marker Wadden $(n=16)$, en (3) bij het voeren van jongen op Marker Wadden (Van der Winden \& Dreef 2020).

Het kan zijn dat spiering welswaar een geliefde prooi is maar dat de vangkans doorgaans klein is en dat gemakkelijker alternatieven meer voor de hand liggen. De waarnemingen vanuit het vliegtuig suggereren dat zo'n $25 \%$ van de waargenomen visdieven op dat moment zich ophield bij aalfuikenvissers. Het is mogelijk dat het vangstsucces daar aanzienlijk groter is, en dat visdieven na veel kortere tijd al een prooi weten te bemachtigen, dan wanneer ze sociaal foerageren op scholen spiering. In dat geval wordt een aanzienlijk groter deel van de voedselvoorziening voor de jongen gehaald uit bijvangsten van aalfuiken (fractie waargenomen visdieven maal (hoog) vangstsucces, ten opzichte van de fractie waargenomen in open water x (laag) vangstsucces). Zoals genoemd zijn de waargenomen concentraties visdieven vanuit de lucht en de identificaties van foto's van foeragerende visdieven anekdotisch en niet representatief. Gezien het feit dat er geen pos en weinig baars/blankvoorn werd aangetroffen in de tientallen bemonsteringen in het open water, maar dat deze soorten veelvuldig werden gevoerd in juli (Figuur 11), doet echter vermoeden dat een aanzienlijk deel van het dieet van visdiefkuikens bestaat uit bijvangst van de aalfuikenvisserij.

Het onderzoek naar foerageergebieden en prooikeuze dat hier is besproken laat zien dat visdieven van Marker Wadden ook in het heldere water van het IJsselmeer goed terecht kunnen en daar zelfs een voorkeur voor lijken te hebben. Het lijkt erop dat ze daarbij voor een belangrijk deel worden geholpen door jagende aalscholvers, futen, mogelijk roofvis en van vissers die hun fuiken legen, dat wil zeggen fenomenen die ervoor zorgen dat prooivis beschikbaar komt aan het oppervlak. Op het Markermeer werden veel minder concentraties visdieven gevonden. Het kan zijn doordat er ook weinig duikende visetende vogels werden waargenomen zoals aalscholvers en futen, waardoor, ondanks het wat troebeler water, toch relatief weinig vis beschikbaar was voor visdieven. Wat betreft roofvis die behulpzaam kan zijn om vis naar het oppervlak te jagen was het bestand op het Markemeer de afgelopen jaren aanzienlijk hoger dan in het IJsselmeer. Het is op dit moment nog onduidelijk of dit ook voor 2020 geldt. Een voorkeur voor het IJsselmeer zou ook kunnen komen doordat hier relatief grote spiering werd waargenomen. Het is echter vooralsnog onduidelijk waarom er dan weinig spiering leek te worden aangevoerd in de kolonies in juli, in tegenstelling tot andere jaren (Van der Winden et al. 2019).

\subsection{Aanbevelingen}

De combinatie van waarnemingen vanuit een vliegtuig, waarnemingen aan de visstand en aan foeragerende sterns en waarnemingen in de kolonie leveren belangrijke puzzelstukken voor de voedselvoorziening en uiteindelijk het broedsucces van visdieven. Er zijn al de nodige studies uitgevoerd en nog gaande aan prooien waarmee jonge visdieven worden gevoerd in de broedkolonies. Een aanzienlijk deel van deze informatie is nog niet uitgewerkt. In aanvulling hierop zijn een aantal puzzelstukjes de moeite waard nader te bekijken die die prooikeuze beter kunnen verklaren vanuit de mogelijke beschikbaarheid van prooien in de potentiele foerageergebieden. 
(1) Prooikeuze in het veld op basis van foto's. Dit is een zeer waardevolle bron van informatie zowel op het water als in de broedkolonies. Er lijkt in het voor dit onderzoek beschikbare materiaal een discrepantie te zitten tussen wat als prooien in het veld werd waargenomen (veel spiering) en wat er in de broedkolonies werd waargenomen (veel pos, weinig spiering). Er zijn echter meer gegevens van zowel broedkolonies als in het veld uit 2020 (onder andere van J. van der Winden, M.R. van Eerden) die nader geanalyseerd kunnen worden in combinatie met het datamateriaal uit dit onderzoek.

(2) Over de prooikeuze van visdieven in het Markermeer is tot dusver weinig bekend. Het is mogelijk om naast aanvullende foto's (zie (1)) fotowaarnemingen van vis die aan kuikens werd gevoerd nader te onderzoeken en te kijken of voldoende nauwkeurige metingen van de lengte van prooien mogelijk is. De lengteverdelingen van bijvoorbeeld spiering, baars en snoekbaars verschilden aanzienlijk tussen beide meren, dus wellicht kan op basis van de lengte van de prooien de herkomst worden achterhaald.

(3) Uit waarnemingen aan boord van het vissersschip leken visdieven kleine prooien als stekelbaars voor zichzelf te houden en andere, grotere, prooien naar de jongen te worden gebracht. Om het belang van verschillende soorten foerageergebieden beter te begrijpen vanuit voedsel voor visdiefouders en voedsel voor de jongen zou de prooikeuze in het veld nader onderzocht moeten worden. Omdat daarbij ook het belang van kleine prooien die snel ingeslikt kunnen worden (zoals stekelbaars) zijn hiervoor snelle acties nodig met behulp van snelle boten en high-speed camera's, een methode die met veel succes is toegepast om bijvoorbeeld het dieet van grote sterns te ontrafelen voor zowel oudervogels als jongen (Perrow et al. 2017).

(4) Het is van belang om een beter inzicht te krijgen in het werkelijke vangstsucces van visdieven door nader te onderzoeken hoe lang een individu op zoek is naar bepaalde prooien. Hoeveel tijd besteden visdieven aan het foerageren op verschillende locaties en bij verschillende voedselbronnen? Wat is het vangstsucces op open water in groepen, in het IJsselmeer en in het Markermeer, achter schepen, of in de buurt van aalfuiken? Dit zou heel goed kunnen worden onderzocht door visdieven uit te rusten met kleine GPS-trackers, waardoor de tijdsbesteding op exacte locaties kan worden onderzocht en het foerageersucces op verschillende locaties kan worden bepaald.

(5) Foerageergebieden op grotere afstand van de broedkolonies. Van visdieven is bekend dat foerageergebieden tot meer dan $20 \mathrm{~km}$ van de broedkolonie kunnen liggen. In dit onderzoek bleken foerageergebieden in een groot deel van het Markermeer een het zuidelijk IJsselmeer te liggen. Met behulp van GPS trackers kan onderzocht worden bij individuele visdieven in hoeverre ook foerageergebieden op nog grotere afstand van belang kunnen zijn onder bepaalde omstandigheden.

(6) Invloed van aalfuikenvisserij op voedselbeschikbaarheid. De bijvangst van aalfuikenvisserij lijkt een belangrijke voedselbron, zowel op basis van de waargenomen prooikeuze als uit het aandeel (bodem)vis in het dieet van visdiefkuikens. Meer directe waarnemingen bij aalfuikenvissers aan prooikeuze is daarbij waardevol. Daarnaast is het ook van belang beter inzicht te krijgen in de omvang en samenstelling van bijvangsten in de fuikenvisserij. Dit kan een bijdrage leveren aan een betere inzicht in het mogelijke belang voor voedselreservering voor vogels in het kader van Natura 2000doelstellingen voor (visetende) watervogels. 


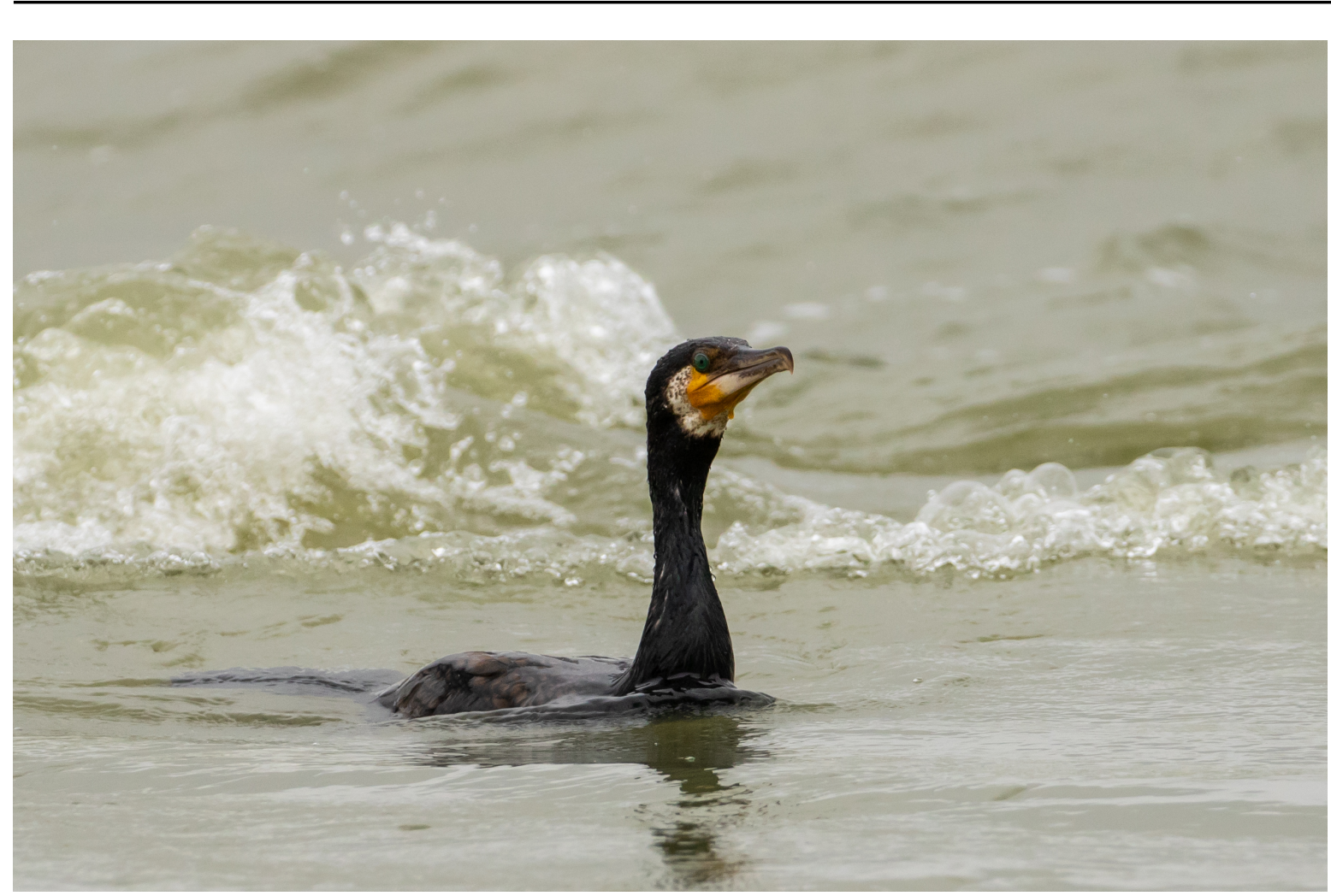

Afbeelding 12 Foeragerende aalscholver (foto: Joep de Leeuw)

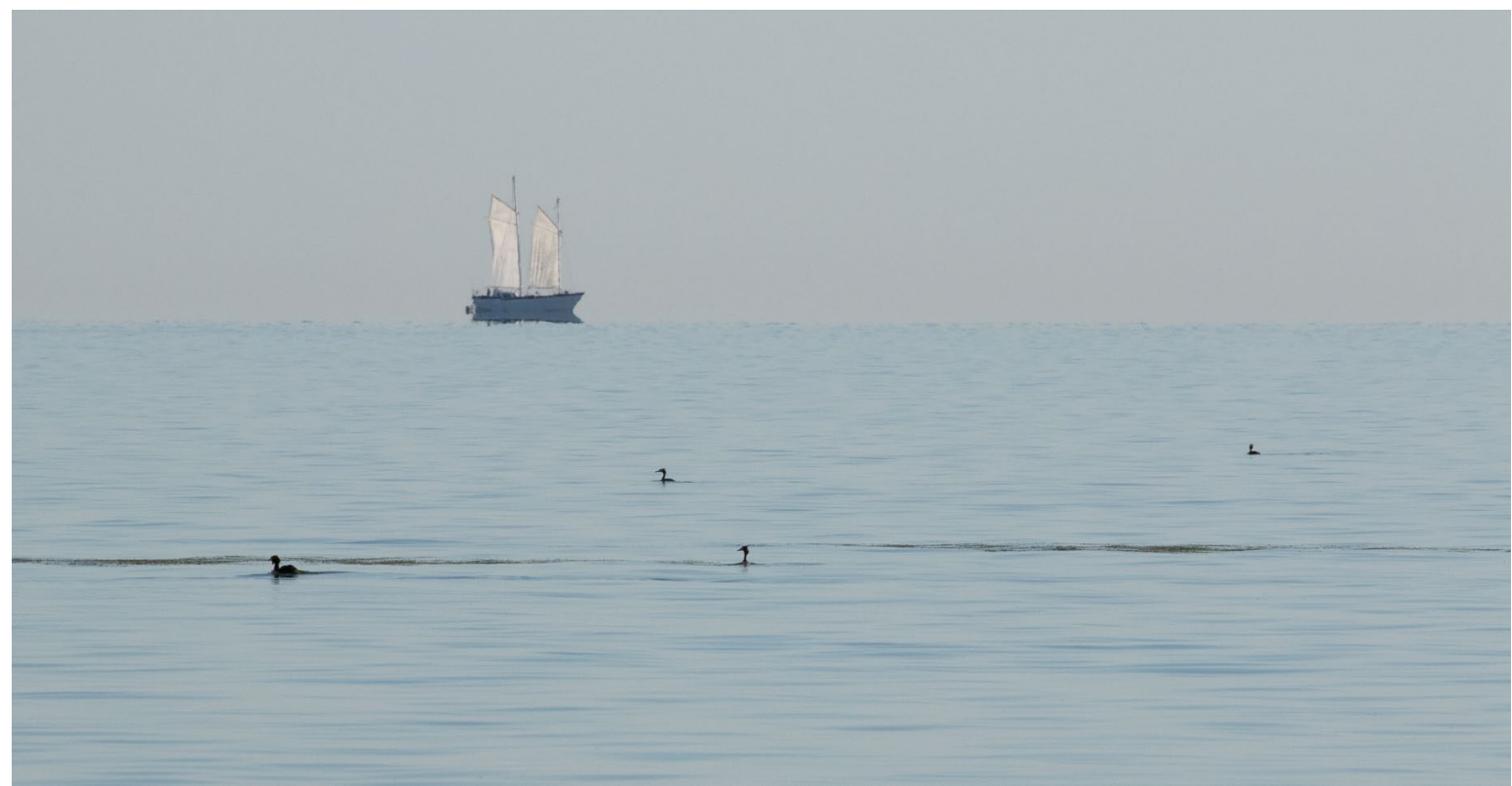

Afbeelding 13 Futen foeragerend tussen fonteinkruidvelden op het Enkhuizerzand (foto: Joep de Leeuw) 


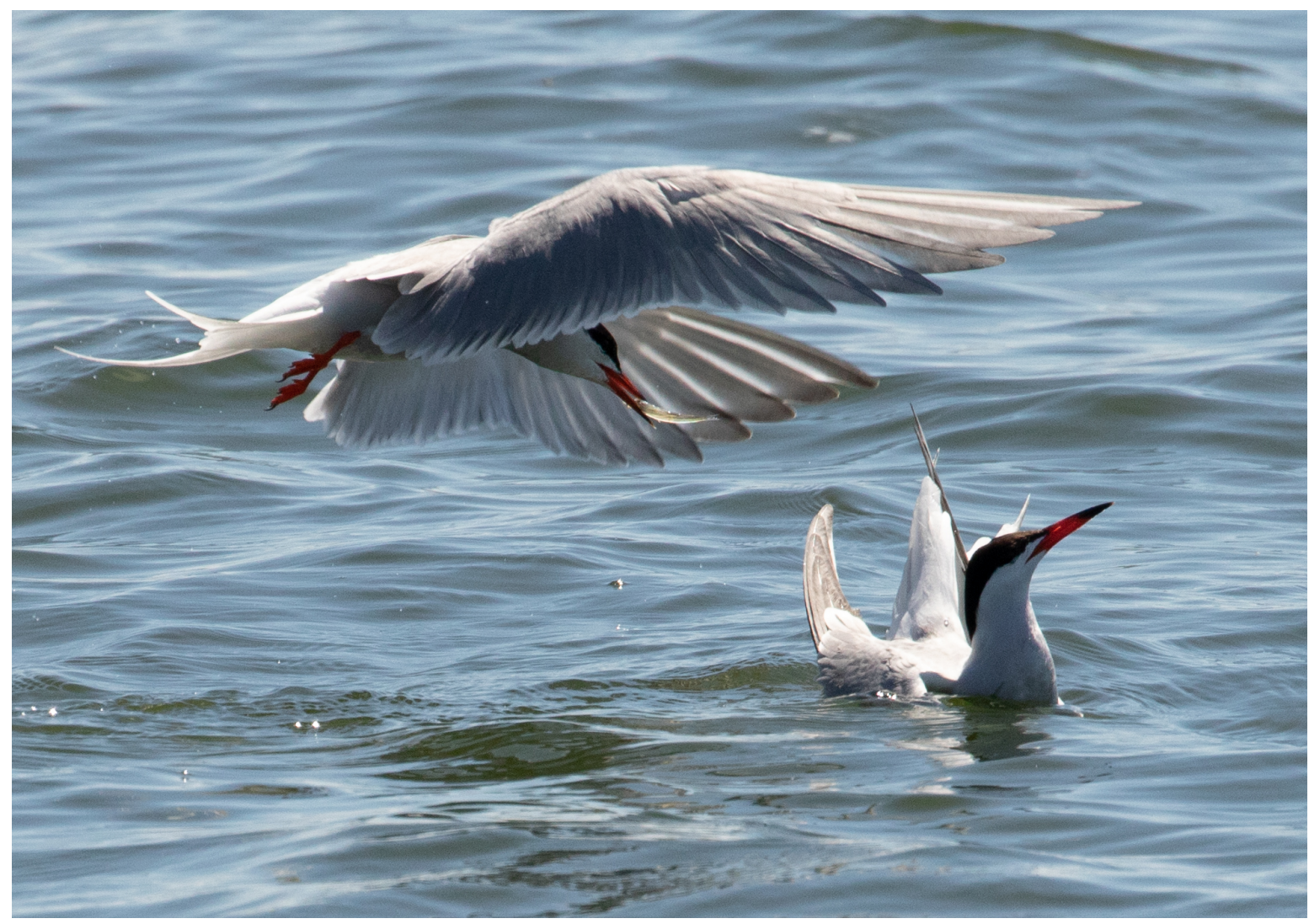

Afbeelding 14 Baltsende visdieven waarbij een spiering wordt aangeboden, IJsselmeer 13 juli 2020 (foto: Joep de Leeuw) 


\section{Kwaliteitsborging}

Wageningen Marine Research beschikt over een ISO 9001:2015 gecertificeerd kwaliteitsmanagementsysteem. Dit certificaat is geldig tot 15 december 2021. De organisatie is gecertificeerd sinds 27 februari 2001. De certificering is uitgevoerd door DNV GL.

Het chemisch laboratorium te IJmuiden beschikt over een EN-ISO/IEC 17025:2017 accreditatie voor testlaboratoria met nummer L097. Deze accreditatie is geldig tot 1 april 2021 en is voor het eerst verleend op 27 maart 1997; deze accreditatie is verleend door de Raad voor Accreditatie. Het chemisch laboratorium heeft hierdoor aangetoond in staat te zijn op technisch bekwame wijze valide resultaten te leveren en te werken volgens de ISO17025 norm. De scope (L097) met de geaccrediteerde analysemethoden is te vinden op de website van de Raad voor Accreditatie (www.rva.nl).

Op grond van deze accreditatie is het kwaliteitskenmerk $\mathrm{Q}$ toegekend aan de resultaten van die componenten die op de scope staan vermeld, mits aan alle kwaliteitseisen is voldaan. Het kwaliteitskenmerk Q staat vermeld in de tabellen met de onderzoeksresultaten. Indien het kwaliteitskenmerk $Q$ niet staat vermeld is de reden hiervan vermeld.

De kwaliteit van de analysemethoden wordt op verschillende manieren gewaarborgd. De juistheid van de analysemethoden wordt regelmatig getoetst door deelname aan ringonderzoeken waaronder die georganiseerd door QUASIMEME. Indien geen ringonderzoek voorhanden is, wordt een tweede lijnscontrole uitgevoerd. Tevens wordt bij iedere meetserie een eerstelijnscontrole uitgevoerd. Naast de lijnscontroles wordende volgende algemene kwaliteitscontroles uitgevoerd:

- Blanco onderzoek.

- Terugvinding (recovery).

- $\quad$ Interne standaard voor borging opwerkmethode.

- Injectie standard.

- Gevoeligheid.

Bovenstaande controles staan beschreven in Wageningen Marine Research werkvoorschrift ISW 2.10.2.105.

Indien gewenst kunnen gegevens met betrekking tot de prestatiekenmerken van de analysemethoden bij het chemisch laboratorium worden opgevraagd.

Indien sprake is van onbeheerste kwaliteit worden passende maatregelen genomen. 


\section{Literatuur}

De Leeuw, J.J. \& I.Y.M. Tulp, 2004. Beschikbaarheid van spiering als voedsel voor vogels in het IJsselmeer. RIVO rapport C004/04.

Dreef C. \& J. van der Winden 2019. Broedvogels en pleisteraars op de Marker Wadden 2017-2019. Rapport 2019-06, Jan van der Winden Ecology, Utrecht.

Gastauer, S., S.M.M. Fässler, A.C. Couperus, A.M. Keller 2013. Target strength and vertical distribution of smelt (Osmerus eperlanus) in the IJsselmeer based on stationary $200 \mathrm{kHz}$ echosounder recordings. Fisheries Research 148: 100-105.

Mous, P.J. 2000. Interactions between fisheries and birds in IJsselmeer, The Netherlands. Thesis, Wageningen University.

Perrow, M., A. Harwood, R. Berridge \& E. Skeate 2017. The foraging ecology of sandwich terns in north Norfolk. British Birds 110: 257-277.

Poot M.J.M., C. Heunks, H.A.M. Prinsen \& J. de Jong 2010. Verspreiding van watervogels op het open water in de nazomer in het IJsselmeergebied. Resultaten van vliegtuigtellingen in augustus 2010. Rapport 10-230. Bureau Waardenburg, Culemborg.

Poot M.J.M., M. Sikkema, M. Hotting \& P.W. van Horssen 2020. Verspreiding van visdieven tijdens het broedseizoen op het open water van Marker- en IJsselmeer. Rapport 2020-01, Martin Poot Ecology, Culemborg.

Tulp, I.Y.M. \& J.J. de Leeuw 2002. Helpt baars zwarte stern? Limosa 75: 123-126.

Van der Winden J., S. Dirksen, \& M. Poot 2018. Visdieven in het IJsselmeergebied.

Aantalsontwikkeling, kolonisatie eilanden en broedsucces. Rapport 2018-02, Jan van der Winden Ecology, Utrecht.

Van der Winden J., S. Dirksen, D. Doodeman, N. Hogeweg, P. Van Horssen, L. Kelder, I. Tulp \& M. Poot. 2019a. Visdieven in het IJsselmeergebied: broedplaatskeuze en broedsucces in een wetland met weinig dynamiek. Limosa 92: 49-64.

Van der Winden J, C. Dreef \& M.J.M. Poot 2019b. Visdieven, dwergsterns en kluten op de Marker Wadden. Jaarrapport 2019: monitoring van aantallen, broedsucces, habitatgebruik en prooikeuze. Rapport 2019-09, Jan van der Winden Ecology, Utrecht.

Van der Winden, J \& C. Dreef 2020. Visdieven en dwergsterns op Marker Wadden in 2020. Jaarrapport: aantallen, broedsucces en prooikeuze als indicatie van relatie tussen vis en vogels. Rapport 2020-0X, Jan van der Winden Ecology, Utrecht. 


\section{Verantwoording}

Rapport C099/20

Projectnummer: 4316100231

Dit rapport is met grote zorgvuldigheid tot stand gekomen. De wetenschappelijke kwaliteit is intern getoetst door een collega-onderzoeker en het verantwoordelijk lid van het managementteam van Wageningen Marine Research

Akkoord:

Mardik Leopold

Senior onderzoeker

Handtekening:

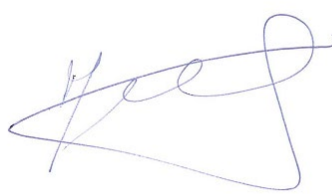

Datum:

20 januari 2021

Akkoord:

Tammo Bult

Directeur

Handtekening:

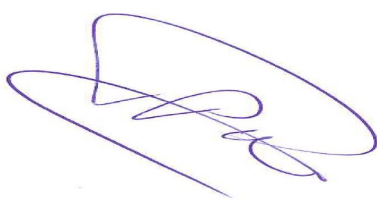

Datum:

20 januari 2021 
Wageningen Marine Research

T: $+31(0) 317480900$

E: marine-research@wur.nl

www.wur.nl/marine-research

Bezoekers adres:

- Ankerpark 271781 AG Den Helder

- Korringaweg 7, 4401 NT Yerseke

- Haringkade 1, 1976 CP IJmuiden
Wageningen Marine Research levert met kennis, onafhankelijk wetenschappelijk onderzoek en advies een wezenlijke bijdrage aan een duurzamer, zorgvuldiger beheer, gebruik en bescherming van de natuurlijke rijkdommen in zee-, kust- en zoetwatergebieden.
Wageningen Marine Research is onderdeel van Wageningen University \& Research. Wageningen University \& Research is het samenwerkingsverband tussen Wageningen University en Stichting Wageningen Research en heeft als missie: 'To explore the potential of nature to improve the quality of life' 